\title{
SURVEY MEASURES OF INFLATION EXPECTATION
}

\author{
Endy Dwi Tjahjono \\ Harmanta \\ Nur M. Adhi Purwato ${ }^{1}$
}

\begin{abstract}
The research objective was to analyze various survey measures of inflation expectation in Indonesia. We found that the heterogeneity of inflation expectationamong economic agents and professional forecastersfor short forecast horizon is very low. Survey measures of inflation expectation appear to be forward looking, but only for relatively short horizon. Although the magnitude and length vary across measures of inflation expectation, we find that shock to inflation expectation significantly affect the dynamics of the actual inflation rate. Based on the accuracy, the effect on actual inflation and directional information that they have in predicting current and future inflation, inflation expectation from Consensus Forecast outperformed the others.
\end{abstract}

Keywords: Inflation expectation, Vector Auto Regression, balanced score.

JEL Classification: C42, E31.

1 EndyDwi Tjahjono (endydt@bi.go.id), Harmanta (harmanta@bi.go.id), and Nur M. Adhi Purwato (adhipd@bi.go.id) are researchers in BRE-DKM Bank Indonesia and are responsible for the results and opinions presented in this paper. We would like to express our gratitude to Mr. Perry Warjiyo, Mr. Iskandar Simorangkir, and other researchers in BRE-DKM that have made contributions in this research. 


\section{PENDAHULUAN}

Peran ekspektasi inflasi dalam menentukan tingkat inflasi telah diakui sebagai sebuah premis penting di negara yang menganut framework kebijakan Inflation Targeting. Sebuah penelitian terbaru di Indonesia yang dilakukan oleh Alamsyah (2008), menunjukkan bahwa setelah melalui masa krisis (2000-2007) inflasi di Indonesia telah berubah dari backward ke forward looking. Penemuan ini sejalan dengan Harmanta (2009) yang menyimpulkan bahwa terdapat peningkatan kredibilitas bank sentral setelah diterapkannya Kerangka Kerja Inflation Targeting secara penuh (kuartal ketiga tahun 2005), yang membuat formasi inflasi menjadi lebih forward looking. Selain itu, menurut Gnan, dkk. (2009), ekspektasi inflasi rendah yang telah dipatok dengan baik secara luas, merupakan indikator penting kredibilitas bank sentral atas komitmennya terhadap stabilitas harga. Argumen ini menekankan pentingnya pengukuran inflasi sebagai informasi penting yang dibutuhkan Bank Indonesia selaku otoritas moneter.

Secara umum, terdapat tiga cara yang dapat digunakan untuk mengukur ekspektasi inflasi. Pertama, melakukan survei kepada pelaku ekonomi, kedua, survei diantara forecaster ekonomi profesional, dan ketiga, berdasarkan informasi pasar uang. Perhitungan ekspektasi inflasi melalui informasi pasar uang telah banyak dilakukan oleh para peneliti di Bank Indonesia. Laksmono, dkk. (2000) mencoba memperoleh ekspektasi inflasi dari suku bunga nominal deposito. Sayangnya, para peneliti percaya bahwa model tersebut tidak memadai dan tidak dapat digunakan untuk mengukur tingkat ekspektasi inflasi. Menurut mereka, hal ini disebabkan oleh pengaruh inflasi yang tidak signifikan dalam menentukan suku bunga deposito. Wuryandani (2001) menggunankan metode SVAR berdasarkan persamaan Fisher untuk mengekstraksi ekpektasi inflasi melalui suku bunga nominal deposito. Berdasarkan penelitian yang dilakukan Wuryandani, dkk. (2003), pengukuran ini kurang unggul dibandingkan dengan pengukuran ekspektasi inflasi SKDU yang memiliki kelebihan dalam memperkirakan inflasi di masa depan. Penelitian terbaru untuk memperoleh ekspektasi inflasi melalui informasi pasar uang dilakukan oleh Kurniati dan Sahminan (2008). Dalam penelitian ini, ekspektasi inflasi diekstraksi dari imbal hasil (yield) Surat Utang Negara (SUN). Anwar dan Chawwa (2008) menemukan bahwa metode ini juga kurang memadai untuk menghitung ekpektasi inflasi karena imbal hasil SUN lebih banyak dipengaruhi oleh perubahan suku bunga kebijakan dan persepsi pasar mengenai kondisi fiskal.

Dalam penelitian ini kita akan berfokus pada dua metode pertama untuk mengukur ekspektasi inflasi, yaitu survei antara pelaku ekonomi dan professional forecaster. Sejumlah studi di negara maju menemukan bahwa ekspektasi inflasi para pelaku ekonomi bersifat heterogen. Selain itu, Gnan, dkk. (2009) berpendapat bahwa ekspektasi inflasi lintas sektor atau lintas para pelaku, dapat saling mempengaruhi. Menganalisa survei pengukuran ekspektasi inflasi memungkinkan kita untuk menguji dua hipotesis sebelumnya yang telah terbukti secara empiris di negara-negara maju. 
Untuk lebih tepatnya, ada 4 pertanyaan penelitian empiris yang coba dijawab, (i) apakah terdapat variasi antara ekspektasi inflasi dari pelaku ekonomi yang berbeda dan apakah ada spillover ekspektasi inflasi lintas pelaku ekonomi?, (ii) apakah survei pengukuran ekspektasi inflasi berhubungan dengan masa lalu, saat ini, atau di masa depan?, (iii) apakah survei pengukuran ekspektasi inflasi mempengaruhi inflasi aktual and seberapa penting guncangan ekspektasi inflasi terhadap dinamika inflasi aktual? Dan (iv) Apakah data survei memberikan informasi arah pergerakan yang berguna untuk tingkat inflasi saat ini dan di masa depan? Selain itu, kita juga akan melihat apakah survei pengukuran ekspektasi inflasi yang tersedia cukup memenuhi tujuan kebijakan moneter, yang berkenaan dengan bervariasinya pelaku ekonomi dan ketersediaan term structure dari ekspektasi inflasi .

Bagian kedua dari paper ini menganalisa literatur teoritis dan empiris, dan bagian ketiga akan menjelaskan metodologi yang digunakan. Hasil dan analisa akan disajikan pada bab empat, sementara kesimpulan akan menutup paper ini.

\section{TEORI}

\subsection{New Keynesian Philips Curve}

Pada akhir tahun 1950an, A.W. Philips mencatat hubungan statistik antara upah, inflasi dan pengangguran di Inggris. Hubungan ini juga ditemukan pada inflasi harga dan kegiatan ekonomi lainnya (Whelan, 2005). Hubungan statistik ini dikenal luas sebagai Kurva Phillips yang pada dasarnya mengatakan bahwa terdapat hubungan terbalik antara inflasi dan tingkat pengangguran. Pada tahun 1968, Milton Friedman mengkritik Kurva Phillips dalam kaitannya dengan perlakuan terhadap ekspektasi inflasi. Selain itu, stagflasi yang merupakan kombinasi antara tingginya tingkat inflasi dan pengangguran pada tahun 1970an tampaknya mendukung kritik Friedman terhadap Kurva Phillips.

Ekonom Keynesian menanggapi kritik ini dan berusaha untuk membangun model yang menggabungkan ekspektasi rasional dan memberikan justifikasi mikroekonomi agar kebijakan moneter memiliki setidaknya efek jangka pendek. Mereka menghasilkan asumsi sticky price yang memungkinkan kondisi dimana tidak semua pasar melakukan kliring sekaligus, dan output agregat terkadang lebih rendah dibanidngkan ketika harga dapat berubah secara fleksibel. Salah satu versi perumusan sticky price yang banyak dikenal adalah Calvo Pricing. Whelan (2005) berpendapat bahwa walaupun perumusan ini bukanlah yang paling realistis, namun dapat memberikan analisa yang mudah dipahami, dan memiliki implikasi yang sangat mirip dengan perumusan lain yang lebih realistis tetapi lebih rumit. Calvo mengasumsikan bahwa dalam setiap periode, hanya sejumlah fraksi random perusahaan ( 1 - $\theta$ ) yang mampu mengatur ulang harga mereka saat perusahaan lain menjaga harga mereka tidak berubah. Jika perusahaan merubah harga, mereka harus memperhitungkan bahwa harga tersebut kemungkinan akan tetap untuk beberapa periode ke depan. Sebuah perusahaan menetapkan harga $\left(z_{t}\right)$ untuk meminimalkan fungsi kerugian berikut ini: 


$$
L\left(z_{t}\right)=\sum_{k=0}^{\infty}(\theta \beta)^{k} E_{t}\left(z_{t}-p_{t+k}^{*}\right)^{2}
$$

Dimana $\beta<1$ merupakan faktor diskon, dan $p^{*}{ }_{t+k}$ merupakan harga optimal yang ditetapkan perusahaan selama periode $t+k$ dalam kondisi tidak adanya kekakuan harga.

Penurunan fungsi kerugian terhadap $z_{t}$ akan menghasilkan persamaan penetapan ulang harga yang optimal sebagai berikut:

$$
z_{t}=(1-\theta \beta) \sum_{k=0}^{\infty}(\theta \beta)^{k} E_{t}\left(\mu+m c_{t+k}\right)
$$

Persamaan ini dicapai dengan asumsi bahwa harga optimal merupakan mark-up yang konstan di atas biaya marjinal:

$$
p_{t}^{*}=\mu+m c_{t}
$$

Agregat tingkat harganya:

$$
p_{t}=\theta p_{t-1}+(1-\theta) z_{t}
$$

Dengan menjabarkan tingkat inflasi: $\pi_{t}=p_{t}-p_{t-1}$, maka dapat disimpulkan menjadi:

$$
\pi_{t}=\beta E \pi_{t+1}+\frac{(1-\theta)(1-\theta \beta)}{\theta}\left(\mu+m c_{t}-p_{t}\right)
$$

Rumus di atas adalah Kurva Keynesian Phillips Baru (NKPC) di mana inflasi merupakan fungsi dari ekspektasi inflasi periode selanjutnya dan biaya marjinal riil $\left(m c_{t}-p_{t}\right)$.

Pada kenyataannya, kita tidak dapat mengamati biaya marjinal riil. Karena biaya marjinal merupakan biaya pro-siklikal, banyak peneliti menggunakan output gap $\left(y_{t}\right)$ dalam persamaan NKPC, maka persamaannya menjadi:

$$
\pi_{t}=\beta E \pi_{t+1}+\frac{(1-\theta)(1-\theta \beta)}{\theta} y_{t}
$$

Gali dan Gertler menawarkan versi "hybrid" NKPC, selain asumsi sama yang telah disebutkan sebelumnya, lebih lanjut juga mengasumsikan bahwa hanya sebagian kecil dari perusahaan yang menetapkan harga yang dipengaruhi oleh inflasi periode sebelumnya (Whelan, 2005). Ide ini didasarkan pada kinerja empiris model NKPC yang tidak maksimal, serta upaya menggabungkan keyakinan para ekonom bahwa tingkat inflasi saat ini adalah fungsi dari nilainilai masa lalunya. NKPC "hybrid" dapat dijabarkan sebagai berikut: 


$$
\pi_{t}=\lambda_{b} \pi_{t-1}+\lambda_{f} E \pi_{t+1}+\frac{(1-\theta)(1-\theta \beta)}{\theta} y_{t}
$$

\subsection{Kriteria Informasi Ekspektasi Inflasi yang dibutuhkan oleh Otoritas Moneter}

Sejumlah studi empiris menemukan bahwa sifat pelaku ekonomi dalam membentuk ekspektasi inflasi mereka, bersifat heterogen. Pelaku-pelaku ekonomi atau sektor-sektor ekonomi mungkin berbeda dalam membentuk ekspektasi inflasi yang dapat menghasilkan perbedaan ekspektasi inflasi secara terus-menerus. Mankiw (2003) menyatakan bahwa heterogenitas ekspektasi inflasi sangat berbeda dari waktu ke waktu, dan akan bergerak seiring dengan inflasi, variabilitas inflasi dan variabilitas harga relatif.

Dari sudut pandang bank sentral, tujuan pemantauan ekspektasi inflasi adalah untuk memperoleh indikasi-indikasi kredibilitas komitmen bank sentral dalam menjaga stabilitas harga, dan mengumpulkan informasi dinamika harga di masa depan. Tergantung dari tujuannya, jenis pelaku-pelaku ekonomi yang ekspektasi inflasinya diawasi, dapat berbeda-beda (Gnan, 2009). Gnan juga menyatakan bahwa otoritas moneter secara bersamaan harus mengawasi ekspektasi inflasi dari berbagai sektor dan pelaku ekonomi (rumah tangga, penentu upah, penentu harga, pasar keuangan dan professional forecaster) karena:

1. Respon kebijakan moneter yang tepat dapat berbeda tergantung pada sektor mana sebuah ekspektasi berasal

2. Bank sentral harus memantau kredibilitasnya pada berbagai pelaku-pelaku atau sektorsektor ekonomi

3. Ekspektasi Inflasi di berbagai pelaku atau sektor ekonomi dapat berpengaruh satu sama lain

Dalam kebanyakan model ekonomi, kebijakan moneter menunjukkan efek inflasi terkuat dalam dua sampai tiga tahun (data di Inggris dan AS). Menurut Gnan (2009), ekspektasi inflasi hingga 12 bulan ke depan kurang lebih berbicara tentang efek tingkat harga ketimbang kredibilitas kebijakan moneter itu sendiri. Sebaliknya, Landau (2009) berpendapat bahwa kebijakan moneter dan komunikasi terkait harus mempertimbangkan ekspektasi inflasi secara bersamaan dalam berbagai rentang waktu dan tidak hanya bertumpu pada ekspektasi inflasi jangka panjang. Penelitian yang dilakukan oleh Dewati, Suryaningsih dan Chawwa (2009) menyimpulkan bahwa guncangan dalam bentuk peningkatan suku bunga riil SBI akan direspon dengan penurunan inflasi pada kuartal mendatang hingga 4 kuartal berikutnya, dengan efek terbesar di dua kuartal pertama. Di sinilah dapat disimpulkan, untuk kasus Indonesia, diharapkan Bank Indonesia memiliki struktur informasi berjangka terhadap dinamika perkembangan ekspektasi inflasi untuk 1 sampai 4 kuartal berikutnya. 


\section{METODOLOGI}

Untuk menganalisis perilaku data survei (heterogenitas dan spillovers antar indikator yang berbeda) dan korelasinya dengan inflasi aktual, kita menggunakan analisis grafis, analisis korelasi dan uji kausalitas granger. Untuk menguji apakah pengukuran survei ekspektasi inflasi memiliki efek pada dinamika inflasi aktual, kita menggunakan analisis VAR (Vector Auto Regression). Untuk menganalisa potensi informasi tentang arah pergerakan survei ekspektasi inflasi dalam memprediksi tingkat inflasi saat ini dan masa depan, kita membandingkan kekuatan prediktif tambahan dari model inflasi sederhana jika kita menambahkan ekspektasi inflasi sebagai salah satu variabel independen dalam model.

Kita menggunakan data survei yang diterbitkan oleh Direktorat Statistik Ekonomi dan Moneter - Bank Indonesia untuk Survei Konsumen (SK), Survei Penjualan Eceran (SPE) dan Survei Kegiatan Dunia Usaha (SKDU). Untuk analisis dalam paper ini, kita menggunakan ekspektasi inflasi kuartalan dari ramalan konsensus yang diterbitkan oleh Consensus Economic. Selain ekspektasi inflasi kuartalan, Consensus Forecast juga menerbitkan ekspektasi inflasi saat ini dan tahun berikutnya setiap bulan. Namun, data ini memiliki kegunaan yang sangat terbatas karena data-data tersebut tidak memiliki forecast horison yang tetap, dan untuk dapat menganalisis dengan tepat perilaku data ini terkait dengan hubungannya dengan data survei lain dan inflasi aktual, kita perlu menganalisa data secara terpisah menurut bulan penerbitannya. Cara ini akan menghasilkan ketersediaan poin data yang sangat singkat. Ringkasan informasi mengenai semua survei yang kita gunakan dalam penelitian ini dapat dilihat dalam Tabel 1.

Untuk data inflasi aktual ( $q$ tq dan yoy), kita menggunakan tingkat inflasi yang dipublikasikan oleh Badan Pusat Statistik Indonesia (BPS). Kita menghitung tingkat inflasi selama 6 bulan berdasarkan Indeks Harga Konsumen yang dikeluarkan oleh BPS. Data nilai tukar perdagangan kuartalan diperoleh dari model SOFIE (Short Term Forecast for Indonesian Economy). Output gap (kuartal) dihitung menggunakan proses multivariat berdasarkan pengangguran dan pendekatan utilisasi kapasitas. Penjelasan secara rinci mengenai pendekatan ini disajikan dalam data Tjahjono et al. (2009).

Sebagaimana dijelaskan dalam tabel 1, di Indonesia, terdapat beragam ukuran ekspektasi inflasi dari berbagai pelaku ekonomi. Untuk setiap pelaku, terkadang diperoleh beragam horison waktu yang berbeda:

- SK dan SPE memiliki informasi mengenai tingkat harga untuk 3 dan 6 bulan berikutnya (kuartal 1 dan 2 berikutnya)

- SKDU memiliki informasi mengenai tingkat harga untuk kuartal berikutnya (semua publikasi), ekspektasi inflasi dua kuartal berikutnya (dalam publikasi kuartal kedua), ekspektasi inflasi dua kuartal berikutnya (dalam publikasi kuartal pertama), dan ekspektasi inflasi empat kuartal berikutnya (dalam publikasi kuartal keempat). 


\begin{tabular}{|c|c|c|c|c|c|}
\hline \multicolumn{6}{|c|}{$\begin{array}{c}\text { Tabel } 1 . \\
\text { Ringkasan Survei yang Berisi Data Ekspektasi Inflasi } \\
\text { Survei antar Pelaku Ekonomi }\end{array}$} \\
\hline Indikator & Pelaku & Frekuensi & Data & $\begin{array}{l}\text { Horison waktu } \\
\text { (dalam kuartalan) }\end{array}$ & Ketersediaan \\
\hline \multirow{2}{*}{$\begin{array}{l}\text { Survei } \\
\text { Konsumen }\end{array}$} & \multirow{2}{*}{ Konsumen } & \multirow{2}{*}{ Bulanan } & $\begin{array}{l}\text { 1. Perubahan kuartal } \\
\text { berikutnya (indeks) }\end{array}$ & $t+1$ & $\begin{array}{l}\text { Setiap bulan sejak } \\
\text { Januari } 2006\end{array}$ \\
\hline & & & $\begin{array}{l}\text { 2. Perubahan Harga } \\
\text { kuartal berikutnya }\end{array}$ & $t+2$ & $\begin{array}{l}\text { Setiap bulan sejak } \\
\text { Maret } 2003\end{array}$ \\
\hline \multirow{2}{*}{$\begin{array}{l}\text { Survei } \\
\text { penjualan } \\
\text { eceren }\end{array}$} & \multirow{2}{*}{ Pengecer } & \multirow{2}{*}{ Bulanan } & $\begin{array}{l}\text { 1. Perubahan kuartal } \\
\text { berikutnya (indeks) }\end{array}$ & $t+1$ & $\begin{array}{l}\text { Setiap bulan sejak } \\
\text { Januari } 2002\end{array}$ \\
\hline & & & $\begin{array}{l}\text { 2. Perubahan Harga } \\
\text { kuartal berikutnya }\end{array}$ & $t+2$ & $\begin{array}{l}\text { Setiap bulan sejak } \\
\text { Januari } 2002\end{array}$ \\
\hline \multirow{3}{*}{$\begin{array}{l}\text { Survei } \\
\text { Kegiatan } \\
\text { Dunia } \\
\text { Usaha }\end{array}$} & \multirow{3}{*}{ Perusahaan } & \multirow{3}{*}{ Kuartal } & $\begin{array}{l}\text { 1. Perubahan kuartal } \\
\text { berikutnya (indeks) }\end{array}$ & $t+1$ & $\begin{array}{l}\text { Setiap kuartal sejak } \\
\text { 1999-Q1 }\end{array}$ \\
\hline & & & $\begin{array}{l}\text { 2. Akhir tahun ekspektasi } \\
\text { inflasi (\% yoy) }\end{array}$ & $t+1, t+2, t+3$ & $\begin{array}{l}\text { untuk setiap horison } \\
\text { t+k, setiap Q(4-k), } \\
\text { sejak } 2003 \text { Q1 }\end{array}$ \\
\hline & & & $\begin{array}{l}\text { 3. Ekspektasi inflasi tahun } \\
\text { berikutnya (\% yoy) }\end{array}$ & $t+4$ & $\begin{array}{l}\text { Setiap Q4, } \\
\text { sejak 2003 Q4 }\end{array}$ \\
\hline
\end{tabular}

\begin{tabular}{|c|c|c|c|c|c|}
\hline \multicolumn{6}{|c|}{ Survei antar Peramal Profesional / Ekonom } \\
\hline Indikator & Pelaku & Frekuensi & Data & $\begin{array}{l}\text { Horison waktu } \\
\text { (dalam kuartalan) }\end{array}$ & Ketersediaan \\
\hline \multirow{3}{*}{$\begin{array}{l}\text { Survei } \\
\text { Persepsi } \\
\text { Pasar }\end{array}$} & \multirow{3}{*}{$\begin{array}{l}\text { Peramal } \\
\text { profesional / } \\
\text { Ekonom }\end{array}$} & \multirow{3}{*}{ Kuartal } & $\begin{array}{l}\text { 1. Inflasi kuartal berikutnya } \\
\text { (\% yoy, range) }\end{array}$ & $t+1$ & $\begin{array}{l}\text { Setiap kuartal, } \\
\text { sejak 2004Q2 }\end{array}$ \\
\hline & & & $\begin{array}{l}\text { 2. Akhir tahun ekspektasi } \\
\text { inflasi (\% yoy, range) }\end{array}$ & $t+1, t+2, t+3$ & $\begin{array}{l}\text { Untuk setiap horison } \\
\text { t+k, setiap Q(4-k), } \\
\text { sejak 2004Q2 }\end{array}$ \\
\hline & & & $\begin{array}{l}\text { 3. Ekspektasi inflasi tahun } \\
\text { berikutnya (\% yoy,yoy) }\end{array}$ & $t+4$ & $\begin{array}{l}\text { Setap Q4, sejak } \\
\text { 2004Q2 }\end{array}$ \\
\hline \multirow{3}{*}{$\begin{array}{l}\text { Konsensus } \\
\text { Perkiraan }\end{array}$} & \multirow{3}{*}{$\begin{array}{l}\text { Peramal } \\
\text { profesional }\end{array}$} & \multirow{3}{*}{ Bulanan } & $\begin{array}{l}\text { 1. Akhir tahun ekspektasi } \\
\text { inflasi (\% yoy) }\end{array}$ & Beragam & Sejak Des-2000 \\
\hline & & & $\begin{array}{l}\text { 2. Ekspektasi inflasi tahun } \\
\text { berikutnya (\% yoy) }\end{array}$ & Beragam & Sejak Des-2000 \\
\hline & & & $\begin{array}{l}\text { Eskpektasi inflasi kuartal } \\
1-6 \text { berikutnya (\%ypy) }\end{array}$ & $\begin{array}{l}t+1, t+2 \\
t+3, t+4 \\
t+5, t+6\end{array}$ & $\begin{array}{l}\text { Setiap kuartal } \\
\text { sejak 2000-Q4 }\end{array}$ \\
\hline
\end{tabular}

\section{Catatan:}

Penyediaan data survei di atas adalah berdasarkan data yang dipublikasikan oleh DSM (untuk SK,SPE,SKDU,dan SPP). Untuk kesepakatan hasil prediksi, data yang tersedia di Perpustakaan riset BI adalah (untuk hardcopy) dan situs perpustakaan $\mathrm{BI}$ (untuk softcopy) 
- SPP memiliki informasi mengenai ekspektasi inflasi kuartal berikutnya (seluruh publikasi), ekspektasi inflasi dua kuartal berikutnya (dalam publikasi kuartal kedua), ekspektasi inflasi tiga kuartal berikutnya (dalam publikasi kuartal pertama), dan ekspektasi inflasi empat kuartal berikutnya (dalam publikasi kuartal keempat)

- CF memiliki informasi mengenai ekspektasi inflasi untuk horison 1 sampai 6 kuartal ke depan. Selain itu, CF juga memiliki data bulanan pada ekspektasi inflasi tahun saat ini dan tahun berikutnya (rata-rata inflasi bulanan tahun ke tahun)

- Dari semua survei, hanya CF yang memberikan struktur berjangka lengkap tentang dinamika ekspektasi inflasi untuk 1 sampai 4 kuartal berikutnya. Akan menjadi ideal apabila Bank Indonesia memiliki informasi yang sejenis dari survei lainnya. Sebagaimana yang akan terlihat di bab berikutnya, menganalisa hubungan antara ukuran survei yang beragam ekspektasi inflasi mengharuskan survei tersebut memiliki kesamaan dalam hal ukuran dan horison ramalan.

Perlu diperhatikan pada ukuran ekspektasi inflasi CF, ekspektasi inflasi kuartal tahun ke tahun (yoy) yang dipublikasikan oleh CF sebenarnya adalah rata-rata ekspektasi inflasi bulanan (yoy) kuartal tertentu, bukan ekspektasi inflasi yoy kuartal bulan lalu. Hal ini akan menyulitkan analisis bahwa ukuran ini tidak sesuai dengan ukuran dari survei lainnya. Namun demikian, dengan pertimbangan tingkat fluktuasi atau keberagaman diantara inflasi yoy bulanan dalam masing-masing kuartal relatif lebih kecil, maka dalam paper ini, kita juga akan meneliti akurasi, korelasi, dan tambahahan kekuatan prediksi ukuran CF dengan mengasumsikan bahwa ukuran ini sesuai dengan ekspektasi inflasi yoy kuartal akhir (sebagai tambahan untuk mengasumsikan ukuran-ukuran tersebut telah sesuai dengan rata-rata ekspektasi inflasi yoy bulanan setiap kuartal).

\begin{tabular}{|c|c|c|c|c|c|c|c|c|c|c|c|}
\hline \multicolumn{12}{|c|}{$\begin{array}{c}\text { Tabel } 2 . \\
\text { Modifikasi Balance Score }\end{array}$} \\
\hline \multicolumn{8}{|c|}{ Untuk SK6m dan SPE6m } & \multicolumn{4}{|c|}{ Untuk SKDU } \\
\hline T_Survey & T_forecast & SBT & SBT_yoy & T_Survey & T_forecast & SBT & SBT_yoy & T_Survey & T_forecast & SBT & SBT_yoy \\
\hline Okt-06 & Jan-07 & 168.02 & 652.01 & Mar-07 & Sep-07 & 174.10 & 332.54 & $2000-1$ & $2000-2$ & 17.24 & 60.21 \\
\hline Nop-06 & Feb-07 & 154.17 & 643.70 & Apr-07 & Okt-07 & 174.03 & 339.08 & $2000-2$ & $2000-3$ & 15.80 & 61.26 \\
\hline Des-06 & Mar-07 & 163.97 & 648.73 & Mei-07 & Nop-07 & 174.08 & 332.60 & $2000-3$ & $2000-4$ & 19.45 & 61.01 \\
\hline Jan-07 & Apr-07 & 163.33 & 640.71 & Jun-07 & Des-07 & 175.41 & 338.64 & $2000-4$ & $2001-1$ & 12.88 & 65.38 \\
\hline Feb-07 & Mei-07 & 173.58 & 644.05 & Jul-07 & Jan-08 & 177.06 & 342.79 & & & & \\
\hline Mar-07 & Jun-07 & 165.53 & 650.63 & Agust-07 & Feb-08 & 175.51 & 349.20 & & & & \\
\hline Apr-07 & Jul-07 & 164.62 & 652.56 & Sep-07 & Mar-08 & 174.23 & 348.33 & & & & \\
\hline Mei-07 & Agust-07 & 164.08 & 654.38 & & & & & & & & \\
\hline Jun-07 & Sep-07 & 167.96 & 661.99 & & & & & & & & \\
\hline Jul-07 & Okt-07 & 174.38 & 670.35 & & & & & & & & \\
\hline \multicolumn{4}{|c|}{$\begin{array}{l}\text { Jika kita mengansumsikan bahwa indeks } \\
\text { (SBT)) adalah ukuran ekspektasi pergerakan } \\
\text { harga pelaku dari waktu survei hingga tiga bulan } \\
\text { berikutnya, maka kita dapat memperoleh ukuran } \\
\text { ekspektasi inflasi yoy tiga bulan berikutnya dari } \\
\text { pelaku dengan menambahkan } 3 \text { indeks sebelumnya } \\
\text { (dengan masing-masing } 3 \text { lag) dengan indeks } \\
\text { sekarang. }\end{array}$} & \multicolumn{4}{|c|}{$\begin{array}{l}\text { Jika kita mengasumsikan bahwa indeks (SBT) } \\
\text { adalah ukuran ekspetasi pergerakan harga pelaku } \\
\text { dari waktu survei hingga } 6 \text { bulan berikutnya, maka } \\
\text { kita akan memperoleh ukuran ekspektasi inflasi yoy } \\
6 \text { bulan beikutnya dari pelaku dengan menambahkan } \\
1 \text { indeks sebelumnya (dengan lag } 6 \text { bulan) dengan } \\
\text { indeks sekarang. }\end{array}$} & \multicolumn{4}{|c|}{$\begin{array}{l}\text { Jika kita mengansumsikan bahwa indeks (SBT) } \\
\text { adalah ukuran ekspektasi inflasi kuartal berikutnya } \\
\text { (qtq), maka kita akan memperoleh ekspektasi inflasi } \\
\text { yoy kuartal berikutnya dari pelaku dengan } \\
\text { membahkan } 3 \text { indeks sebelumnya dengan indeks } \\
\text { sekarang. }\end{array}$} \\
\hline
\end{tabular}


Sebagaimana ditunjukkan dalam Tabel 1, terdapat dua tipe data ekspektasi inflasi yang kita peroleh dari survei yaitu balance scores (SK, SPE, SKDU) dan tingkat inflasi (concensus forecast, SPP, SKDU akhir tahun inflasi. Survei yang menggunakan balance scores mengukur pergerakan harga periode 3 atau 6 bulan berikutnya. Adapun survei yang menggunakan tingkat inflasi mengukur inflasi yoy untuk horison tertentu. Kedua ukuran tersebut tidak kompatibel satu sama lain. Untuk membandingkannya, kita memodifikasi balance scores agar dapat sesuai dengan ukuran ekspektasi inflasi yoy. Hal ini dilakukan dengan menambahkan balance scores sebelumnya ke balance scores saat ini. Uraian metode modifikasinya dijelaskan dibawah. Sebagaimana yang akan kita lihat pada bab berikutnya, modifikasi ini dapat mengikuti pergerakan inflasi yoy aktual.

\section{HASIL DAN ANALISIS}

\subsection{Korelasi, Heterogenitas, dan}

Spillovers Ekspektasi Inflasi diantara Data Survei. Sebagaimana yang ditunjukkan pada table 3, seluruh survei yang menggunakan ukuran balance scores atau tingkat inflasi memiliki korelasi yang signifikan dengan inflasi aktual pada horison prediksi yang diharapkan. Korelasi dengan inflasi aktual menurun dikarenakan meningkatnya horison prediksi.

\begin{tabular}{|c|c|c|c|c|}
\hline \multicolumn{5}{|c|}{$\begin{array}{c}\text { Tabel } 3 . \\
\text { Korelasi Pengukuran Survei Ekspektasi Inflasi dengan Inflasi Aktual }\end{array}$} \\
\hline \multicolumn{3}{|c|}{$\begin{array}{l}\text { Correlation between balance score } \\
\text { and actual price movement }\end{array}$} & \multicolumn{2}{|c|}{$\begin{array}{l}\text { Cerrelation between inflation forecast/ } \\
\text { expectation and actual inflation }\end{array}$} \\
\hline & Inflation_qtq & Inflation_6m & & Inflation_yoy \\
\hline & & & CF_1Q & 0.7658 \\
\hline SK3bln & 0.53 & - & CF_2Q & 0.5247 \\
\hline SK6bln & - & 0.29 & CF_3Q & 0.2025 \\
\hline SPE3bln & 0.43 & - & CF_4Q & -0.2003 \\
\hline SPE6bln & - & 0.25 & CF_5Q & -0.3097 \\
\hline SKDU & 0.49 & - & CF_6Q & -0.4344 \\
\hline
\end{tabular}

Banyak studi empiris di negara-negara maju yang telah menunjukkan bahwa ekpektasi inflasi dari pelaku ekonomi yang berbeda bersifat heterogen, dan heterogenitas ini bervariasi seiring dengan berjalannya waktu, berubah seiring perubahan inflasi, variabilitas inflasi, dan variabilitas harga-harga relatif. Pada bagian ini, kita akan meneliti heterogenitas ukuran-ukuran ekspektasi inflasi dari beragam pelaku ekonomi. Selain itu, kita juga akan mencoba mendapatkan indikasi spillover apapun yang ada di antara ekspektasi inflasi pelaku tertentu dengan ekspektasi pelaku lainnya.

Berdasarkan asumsi ketersediaan informasi tentang pergerakan harga yang dimiliki oleh para pelaku, kita memperkirakan bahwa ekspektasi inflasi perusahaan akan mempengaruhi ekspektasi inflasi retailer. Sebagai produsen barang dan jasa, perusahaan harus memiliki informasi 
aktual mengenai rencana penentuan harga di masa yang akan datang. Kelompok pelaku selanjutnya yang harus menerima informasi ini adalah retailer dan konsumen. Berdasarkan argumen tersebut, kita juga mengekspektasikan bahwa ekspektasi inflasi retailer akan mempengaruhi ekspektasi inflasi konsumen. Tes kausalitas granger dan korelasi lead/lag merupakan metode-metode yang dipilih untuk menguji hipotesis ini. Untuk itu, kita data ekspektasi inflasi dikelompokkan dengan ukuran-ukuran dan horison waktu yang sesuai:

- SK 3 bulan dan SPE 3 bulan - Data Bulanan

- SK 6 bulan dan SPE 6 bulan - Data Bulanan

- SK 3 bulan, SPE 3 bulan, dan SKDU - Data Kuartalan

- SKDU ( modifikasi yoy), Consensus Forecast 1 Kuartal - Data Kuartalan

- Consensus Forecost 1 kuartal dan SPP 1 kuartal - Data Kuartalan

- Ekspektasi inflasi akhir tahun SKDU dan ekspektasi inflasi akhir tahun SPP - Data Kuartalan

Untuk ekspektasi pergerakan harga 3 dan 6 bulan berikutnya (data bulanan), kita terdapat 2 indikator, yaitu berdasarkan survei konsumen (SK) dan survei retailer (SPE). Seperti yang dapat dilihat pada Grafik 1, untuk pergerakan harga 3 bulan, kedua indikator menunjukkan korelasi

SK3bln vs SPE3bln

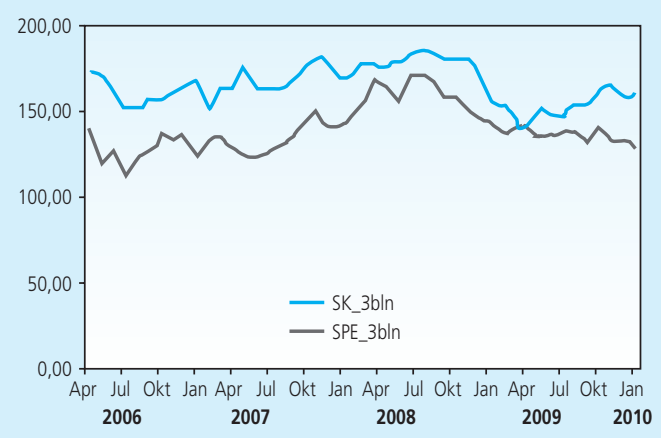

The Result of Granger Causality Test

\begin{tabular}{cllc}
\hline SK3bln & granger cause & SPE3bln & $X$ \\
\hline SP3bln & granger cause & SK3bln & \\
\hline & & & \\
\hline SK6m & granger cause & SPE6m & $X$ \\
\hline SPE6m & granger cause & SK6m & \\
\hline
\end{tabular}

\begin{tabular}{|l|c|} 
Correlation & SK_3bln \\
SK_3bln-2 & 0.5281 \\
\hline SK_3bln-1 & 0.6082 \\
\hline SK_3bln & 0.6554 \\
\hline SK_3bln+1 & $\mathbf{0 . 6 6 8 7}$ \\
\hline SK_3bln+2 & 0.5453 \\
\hline
\end{tabular}


yang tinggi secara signifikan, dengan korelasi tertinggi antara ekspektasi pergerakan harga oleh konsumen pada waktu $t$ dan ekpektasi pergerakan harga retailer pada waktu $t-1 t$ - 1 . Dari sini dapat disimpulkan bahwa ekpektasi pergerakan harga retailer menyebabkan ekspektasi pergerakan harga konsumen sebesar 1 bulan. Untuk ekspektasi pergerakan harga 6 bulan, terjadi hal yang sama dimana ekspektasi retailer menyebabkan ekspektasi konsumen sebesar 1 bulan. Dari analisis korelasi dan tes kausalitas granger, dapat dilihat bahwa terdapat kemungkinan spillover ekspektasi inflasi dari retailer ke konsumen.

Untuk ekspektasi pergerakan harga kuartal selanjutnya, kita terdapat 3 indikator, yaitu berdasarkan survei konsumen, retailer, dan perusahaan. Seperti yang tertera pada grafik 2, semua indikator menunjukkan korelasi yang tinggi pada waktu $t$. Karena kita menggunakan data kuartal, kita tidak melihat kesamaan fenomena seperti yang terlihat pada data bulanan dimana ekspektasi retailer menyebabkan ekspektasi konsumen. Namun, menurut hasil tes kausalitas granger diantara semua indikator cenderung memperlihatkan bahwa ekspektasi konsumen dipengaruhi oleh ekspektasi retailer. Jika kita menggunakan data kuartalan, ekspektasi pergerakan harga konsumen, retailer, dan perusahaan terlihat seakan bergerak bersama dengan korelasi yang sangat tinggi di antara mereka. Ini mungkin menunjukkan bahwa heterogenitas ekspektasi inflasi di antara para pelaku ini sangatlah rendah.

\section{SK3bln vs SPE3bln vs SKDU (Quarterly Data)}

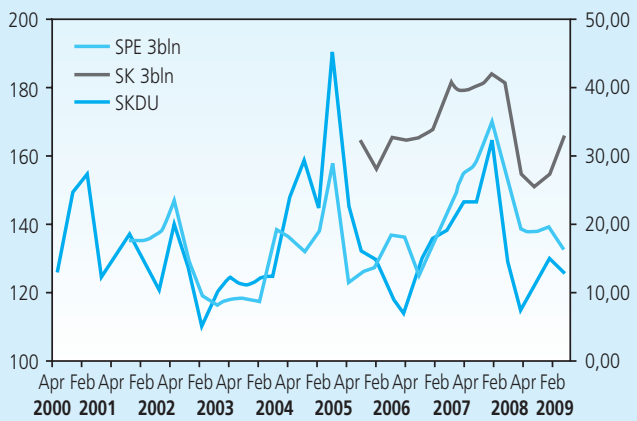

The Result of Granger Causality Test

\begin{tabular}{|c|c|c|c|}
\hline SK3bln & Granger cause & SKDU & $x$ \\
\hline SKDU & Granger cause & SK3bln & $X$ \\
\hline SK3bln & Granger cause & SKDU & $x$ \\
\hline SKDU & Granger cause & SK3bln & $x$ \\
\hline SK3bln & Granger cause & SPE3bln & $x$ \\
\hline SPE3bln & Granger cause & SK3bln & $\checkmark$ \\
\hline
\end{tabular}

\begin{tabular}{r|c|c|c|c|c|c|c|c|c|c|c} 
Correlation & SKDU & Correlation & SKDU & Correlation & SPE & Correlation & SPE & Correlation & SK3bln & Correlation & SK3bln \\
SK3bln-3 & 0.2055 & SPE3bln-3 & -0.1139 & SK3bln-3 & 0.6165 & SKDU-3 & 0.0969 & SPE3bln-3 & -0.1802 & SKDU-3 & -0.5014 \\
\hline SK3bln-2 & 0.2613 & SPE3bln-2 & -0.0167 & SK3bln-2 & 0.5569 & SKDU-2 & 0.2684 & SPE3bln-2 & 0.0431 & SKDU-2 & -0.2432 \\
\hline SK3bln-1 & 0.3378 & SPE3bln-1 & 0.2336 & SK3bln-1 & 0.7313 & SKDU-1 & 0.3157 & SPE3bln-1 & 0.5556 & SKDU-1 & 0.5797 \\
\hline SK3bln-0 & 0.8197 & SPE3bln-0 & 0.7926 & SK3bln-0 & 0.7722 & SKDU-0 & 0.604 & SPE3bln-0 & 0.8217 & SKDU-0 & 0.7699 \\
\hline SK3bln+1 & 0.7556 & SPE3bln+1 & 0.7713 & SK3bln+1 & 0.3765 & SKDU+1 & 0.3375 & SPE3bln+1 & 0.7077 & SKDU+1 & 0.5000 \\
\hline SK3bln+2 & 0.1407 & SPE3bln+2 & 0.3927 & SK3bln+2 & 0.283 & SKDU+2 & 0.0337 & SPE3bln+2 & 0.482 & SKDU+2 & 0.2149 \\
\hline SK3bln+3 & -0.3922 & SPE3bln+3 & 0.0555 & SK3bln+3 & -0.6805 & SKDU+3 & -0.1231 & SPE3bln+3 & 0.4149 & SKDU+3 & 0.0728
\end{tabular}

Grafik 2.

Korelasi Ekspektasi Inflasi dari Survei Konsumen, Survei Retailer, dan Survei Bisnis 
Seperti yang telah dibahas sebelumnya, data Consensus Forecast (CF) sebenarnya mengukur rata-rata bulanan ramalan inflasi yoy setiap kuartalnya, tetapi untuk analisis di bagian ini, kita akan digunakan Indikator CF seolah-olah indikator tersebut mengukur ekspektasi inflasi yoy per kuartal (ekspektasi inflasi yoy pada bulan terakhir di setiap kuartal). Indikator yang sesuai untuk 1 kuartal Consensus Forecast adalah balance scores SKDU. Balance scores ini telah dimodifikasi agar sesuai dengan pengukuran inflasi yoy (penjelasan lebih lanjut mengenai modifikasi ini dapat dilihat di lampiran). Grafik 3 menunjukkan bahwa kedua indikator (CF dan SKDU) mempunyai korelasi tinggi yang signifikan, dengan korelasi paling tinggi terjadi antara ekspektasi inflasi perusahaan pada waktu $t$ dan ekspektasi inflasi analis professional pada waktu $t+1$. Ekspektasi inflasi perusahaan tampaknya menyebabkan ekspektasi inflasi CF sebesar 1 kuartal. Berdasarkan hal ini dan hasil tes kausalitas granger, kita dapat menyimpulkan bahwa sepertinya terdapat indikasi bahwa ekspektasi inflasi oleh analis professional dipengaruhi oleh ekpektasi inflasi perusahaan.

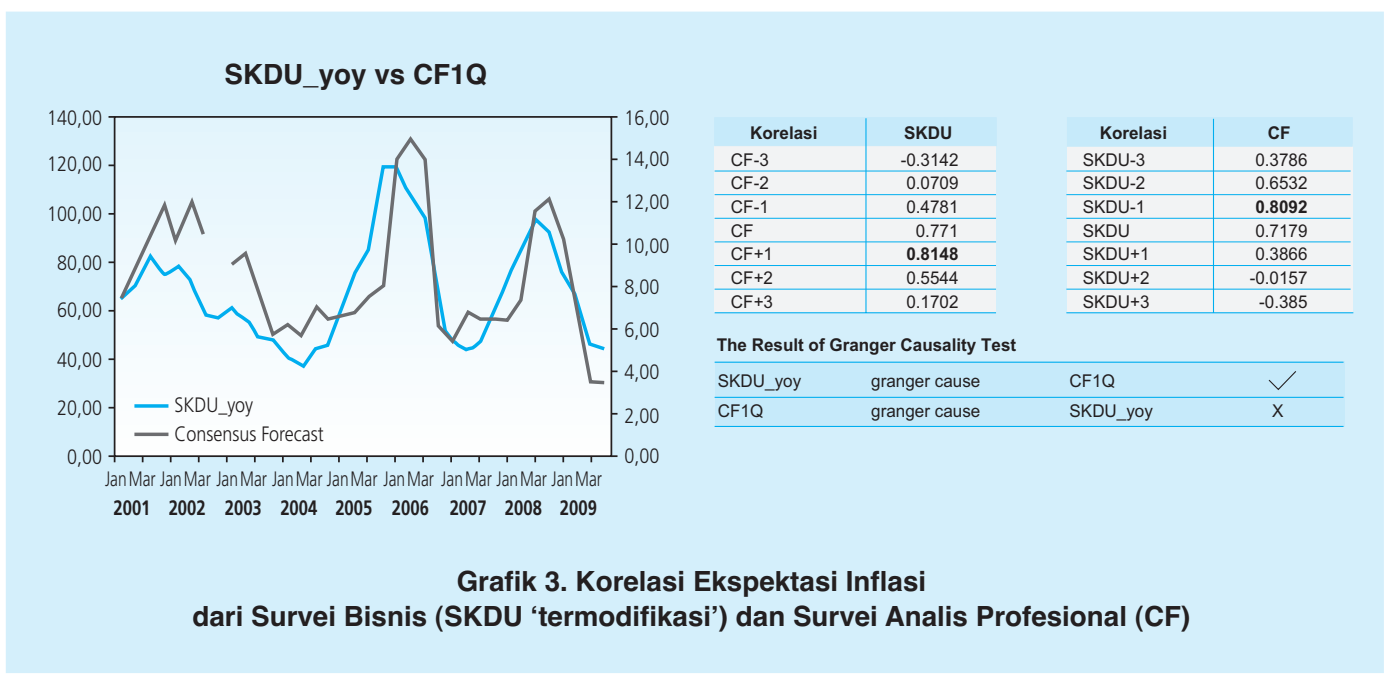

Survei Persepsi Pasar (SPP) menyajikan modus kuartal berikutnya dan kisaran ekspektasi inflasi akhir tahun. Analisa korelasi yang telah dilakukan terhadap indikator lain tidak dapat digunakan untuk menganalisa data SPP, jadi kita akan menggunakan analisa grafik. Indikator yang sesuai untuk ekspektasi inflasi kuartal berikutnya adalah Consensus Forecast 1 Kuartal, dan untuk ekspektasi inflasi akhir tahun digunakan SKDU-akhir tahun. Seperti yang dapat kita lihat pada Grafik 4, untuk ekspektasi inflasi kuartal berikutnya, analisis dari CF selalu berada dalam kisaran modus SPP. Untuk horison pendek, seperti yang ditunjukkan oleh surveisurvei yang lain, heterogenitas ekspektasi inflasi antara CF dan SPP sangat rendah. Untuk ekspektasi inflasi akhir tahun, baik SPP maupun SKDU menghasilkan data yang sama. Untuk setiap kuartal pertama, kedua, dan ketiga, setiap survei menanyakan kepada responden mengenai ekspektasi inflasi kuartal keempat pada tahun yang sama. Sementara pada kuartal 
keempat setiap tahunnya mereka menanyakan ekspektasi inflasi responden untuk kuartal keempat tahun berikutnya. Seperti yang dapat kita lihat dari Gambar 4, sebagian besar, responden-responden SKDU memiliki ekspektasi inflasi yang lebih tinggi daripada respondenresponden SPP. Horison dari data ini sebagian besar lebih lama dari 1 kuartal. Untuk horison yang lebih lama ini, kita mengobservasi bahwa heterogenitas ekspektasi inflasi antara SPP dan SKDU lebih tinggi daripada apa yang kita temukan pada survei-survei yang lain untuk 1 kuartal sebelum horison.

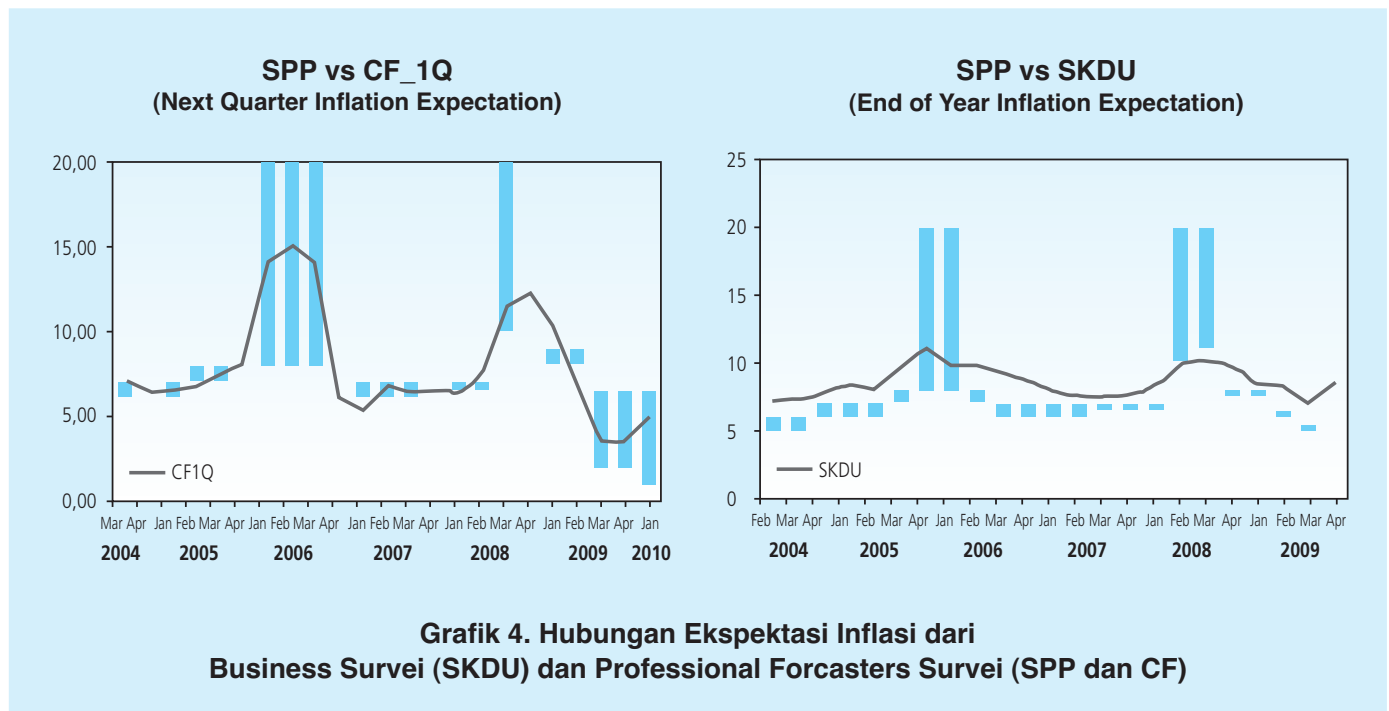

Diantara survei-survei yang kompatibel yang menggunakan metode balance scores, kita menemukan bahwa survei tersebut memiliki korelasi tinggi. Semakin panjang horison forecast, tingkat korelasi antara survei menurun. Kita menemukan kejadian sama pada surveisurvei yang menanyakan responden tentang tingkat ekspektasi inflasi di masa depan. Korelasi antara survei horison forecast dalam 1 kuartal ke depan sangat tinggi. Sebaliknya, kita menemukan bahwa ekspektasi inflasi dari responden SKDU (Mean) selalu lebih tinggi dari ekspektasi responden SPP (Modus) untuk forecast horison lebih dari 1 kuartal.

Dari analisis pada bagian ini, kita menyimpulkan bahwa untuk jangka peramalan 1 kuartal, tingkat heterogenitas dari ekspektasi inflasi di perusahaan (SKDU), konsumen (SK), pengecer (SPE), dan forecaster profesional (SPP dan CF) sangat rendah. Fakta yang ditunjukkan dari analisis korelasi dan uji kausalitas Granger menunjukkan bahwa ekspektasi inflasi konsumen bisa "dipengaruhi" oleh ekspektasi inflasi pengecer, dan ekspektasi inflasi dari forecaster profesional bisa "dipengaruhi" oleh ekspektasi inflasi perusahaan. 


\subsection{Hubungan dengan Inflasi masa lalu, sekarang, dan masa depan}

Bagian inikita mengkaji korelasi antara pengukuran survei ekspektasi inflasi dengan inflasi aktual. Seperti kita bagian sebelumnya, kita tidak hanya tertarik pada korelasi ekspektasi inflasi dan inflasi aktual pada horison forecast yang dimaksud, namun juga menghubungkannya dengan inflasi yang lalu dan saat ini (dihitung sesuai waktu saat survei dilakukan). Analisis korelasi dapat dilakukan dengan data balance scores dan data tingkat inflasi. Kita juga akan menguji akurasi survei tingkat ekspektasi inflasi dengan melihat kemampuan dalam memprediksi tingkat inflasi pada horison forecast yang diinginkan.

Dari grafik 5, dapat dilihat bahwa balance scores SK 3 bulan sangat berkorelasi dengan inflasi di 3 bulan selanjutnya, namun korelasi tertinggi terjadi pada tingkat inflasi qtq saat itu. Hal yang sama terjadi pada balance scores SK 6 bulan, dimana nilai tersebut sangat berkorelasi dengan inflasi di 6 bulan selanjutnya, namun korelasi tertinggi terjadi pada inflasi di 3 bulan pertama. Korelasi yang lebih tinggi pada inflasi di masa depan dibandingkan masa lampau dapat menggambarkan perilaku konsumen yang bersifat forward looking dalam membentuk ekspektasi inflasi. Meskipun perlu diperhatikan bahwa konsumen masih

SK_3bln

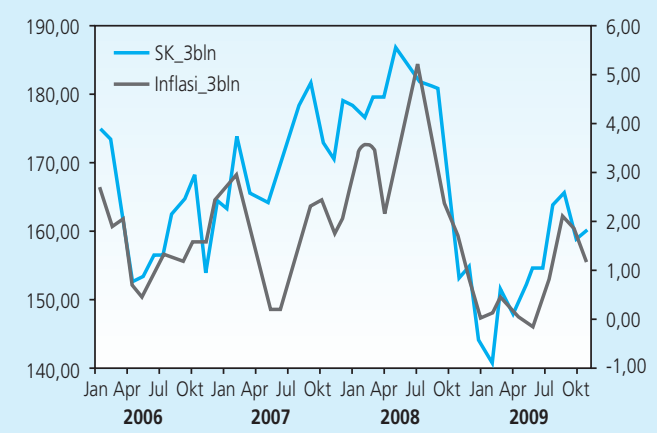

SK_6bln

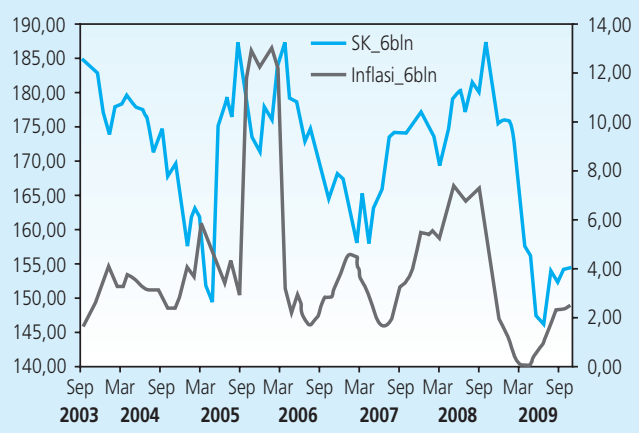

\begin{tabular}{|c|c|c|c|c|c|}
\hline Korelasi & SK_3bln & Korelasi & SK_6bln & Korelasi & SK_6bln \\
\hline inflasi3m-3 & 0.2376 & inflasi6m-6 & -0.3447 & inflasi6m & 0.4014 \\
\hline inflasi3m-2 & 0.4121 & inflasi6m-5 & -0.2328 & inflasi6m+1 & 0.4878 \\
\hline inflasi3m-1 & 0.5610 & inflasi6m-4 & -0.1038 & inflasi $6 m+2$ & 0.4848 \\
\hline inflasi3m & 0.7994 & inflasi6m-3 & -0.0184 & inflasi $6 m+3$ & 0.4875 \\
\hline inflasi3m+1 & 0.7902 & inflasi6m-2 & 0.1092 & inflasi $6 m+4$ & 0.4266 \\
\hline inflasi3m+2 & 0.6909 & inflasi6m-1 & 0.2466 & inflasi $6 m+5$ & 0.3700 \\
\hline inflasi3m+3 & 0.5330 & inflasi6m & 0.4014 & inflasi $6 m+6$ & 0.2940 \\
\hline
\end{tabular}

Grafik 5.

Korelasi ekspektasi inflasi pada Survei Konsumen (SK) dan Inflasi Aktual. 
banyak mempertimbangkan keadaan tingkat inflasi pada saat itu ketika membentuk ekpektasi inflasi.

Balance scores SK seharusnya menunjukkan indikasi ekspektasi pergerakan harga dalam tiga atau enam bulan selanjutnya, sehingga akan dapat digunakan dalam perhitungan qtq atau inflasi selama 6 bulan. Untuk mendapatkan perhitungan yang sesuai pada inflasi yoy selama tiga atau enam bulan selanjutnya, kita menambah balance scores sebelumnya dengan balance scores yang terjadi saat itu (3 balance scores sebelumnya dengan interval 3 bulan untuk balance scores di 3 bulan selanjutnya; dan 1 balance scores sebelumnya dengan interval 6 bulan untuk balance scores 6 bulan). Salah satu hambatan dengan pendekatan ini adalah bahwa balance scores yang telah dimodifikasi tidak hanya berdasarkan informasi yang tersedia bagi responden pada saat survei dilakukan, namun juga berdasarkan informasi yang tidak lengkap, yang ada sebelum survei.

SK3bln_yoy vs inflasi_yoy

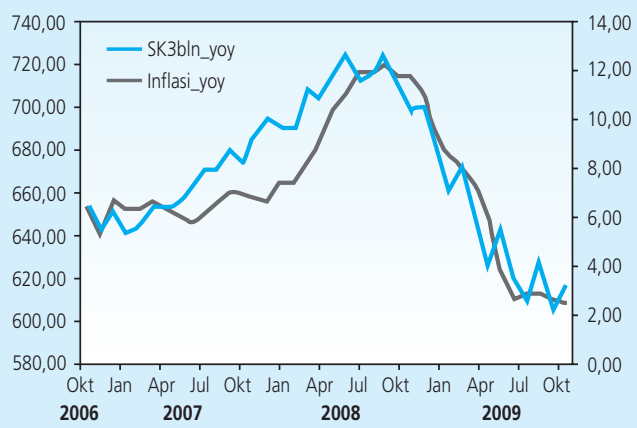

SK6bln_yoy

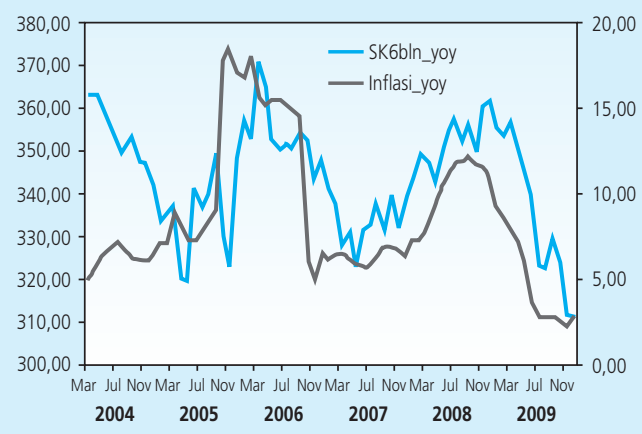

SK_6bln_yoy $-0.3176$ $-0.2356$ $-0.1708$ $-0.0952$ $-0.0017$ 0.132 0.304

\begin{tabular}{c|c} 
Correlation & SK_6bln_yoy \\
inflasiyoy+1 & $\mathbf{0 . 4 6 1 6}$ \\
\hline inflasiyoy+2 & $\mathbf{0 . 5 1 7 4}$ \\
\hline inflasiyoy+3 & $\mathbf{0 . 5 5 6 8}$ \\
\hline inflasiyoy+4 & $\mathbf{0 . 5 6 4 3}$ \\
\hline inflasiyoy+5 & $\mathbf{0 . 5 1 2 9}$ \\
\hline inflasiyoy+6 & 0.451
\end{tabular}

Grafik 6. Korelasi Ekspektasi Inflasi dari Survei Konsumen (Indeks SK yang telah dimodifikasi) dan Inflasi Aktual.

Dari grafik 5 kita melihat bahwa terdapat korelasi yang tinggi antara balance scores 3 bulan yang dimodifikasi dengan inflasi yoy pada 3 bulan selanjutnya, namun korelasi tertinggi terjadi pada inflasi yoy di 2 bulan selanjutnya. Dapat dilihat juga bahwa terdapat korelasi yang 
SPE3bln

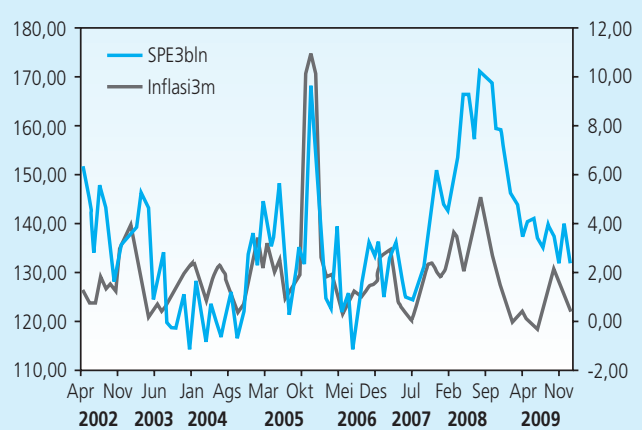

SPE6bln

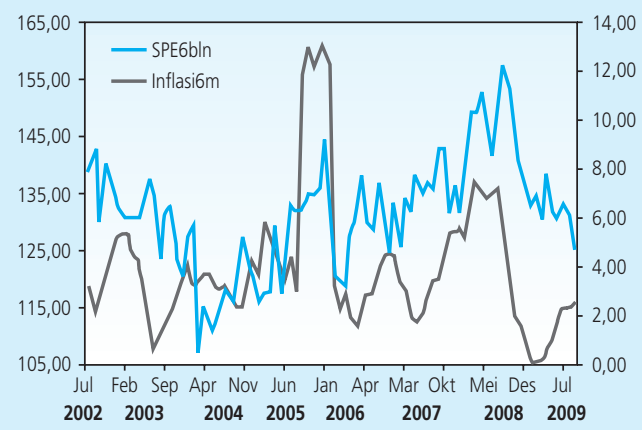

\begin{tabular}{c|c} 
Korelasi & SPE_3bln \\
inflasi3m-3 & -0.0189 \\
\hline inflasi3m-2 & -0.0195 \\
\hline inflasi3m-1 & 0.0446 \\
\hline inflasi3m & 0.0950 \\
\hline inflasi3m+1 & $\mathbf{0 . 2 9 5 0}$ \\
\hline inflasi3m+2 & $\mathbf{0 . 4 7 8 9}$ \\
\hline inflasi3m+3 & $\mathbf{0 . 4 2 8 8}$
\end{tabular}

\begin{tabular}{c|c} 
Korelasi & SPE_6bln \\
inflasi6m-6 & -0.0525 \\
\hline inflasi6m-5 & 0.0270 \\
\hline inflasi6m-4 & 0.0951 \\
\hline inflasi6m-3 & 0.1310 \\
\hline inflasi6m-2 & 0.0791 \\
\hline inflasi6m-1 & 0.0698 \\
\hline inflasi6m & 0.0552
\end{tabular}

\begin{tabular}{c|c} 
Korelasi & SPE_6bln \\
inflasi6m+1 & 0.0403 \\
\hline inflasi6m+2 & 0.0905 \\
\hline inflasi6m+3 & 0.1084 \\
\hline inflasi6m+4 & 0.1764 \\
\hline inflasi6m+5 & 0.2260 \\
\hline inflasi6m+6 & $\mathbf{0 . 2 4 5 5}$ \\
\hline
\end{tabular}

Grafik 7.

Korelasi Ekspektasi Inflasi dari Survei Penjualan Eceran (SPE) dan Inflasi Aktual

tinggi antara balance scores yang dimodifikasi dengan inflasi yoy pada 6 bulan selanjutnya, namun korelasi tertinggi terjadi pada inflasi yoy di 3 dan 4 bulan selanjutnya. Hasil yang dicapai ini sesuai dengan hasil balance scores yang asli (original). Perbedaannya adalah bahwa tingkat korelasi terhadap inflasi di masa depan lebih jelas terlihat.

Grafik 7 menunjukkan korelasi antara ekspektasi inflasi pengecer dengan inflasi yang terjadi (inflasi aktual). Seperti yang kita lihat, balance scores selama 3 bulan dan 6 bulan menunjukkan korelasi yang lebih tinggi pada tingkat inflasi mendatang dibanding tingkat inflasi yang terjadi saat ini dan di masa lalu. Dibandingkan dengan konsumen, dalam membentuk ekspektasi inflasi, pengecer menunjukkan perilaku yang lebih forward looking dan lebih sedikit memperhatikan tingkat inflasi yang terjadi saat itu.

Kita memodifikasi balance scores SPE dengan menggunakan metode yang sama pada balance scores SK. Hasil korelasi dapat dilihat pada Grafik 8. Seperti pada data SK, untuk balance scores selama 3 bulan yang telah dimodifikasi, korelasinya dengan inflasi yoymencapai titik tertinggi pada waktu $t+2$. Dibandingkan dengan balance scores yang tidak dimodifikasi, balance scores 6 bulan yang dimodifikasi menunjukkan korelasi lebih tinggi dengan tingkat inflasi pada 3 bulan selanjutnya, dibandingkan dengan tingkat inflasi selama 6 bulan selanjutnya. 
SPE3bln_yoy

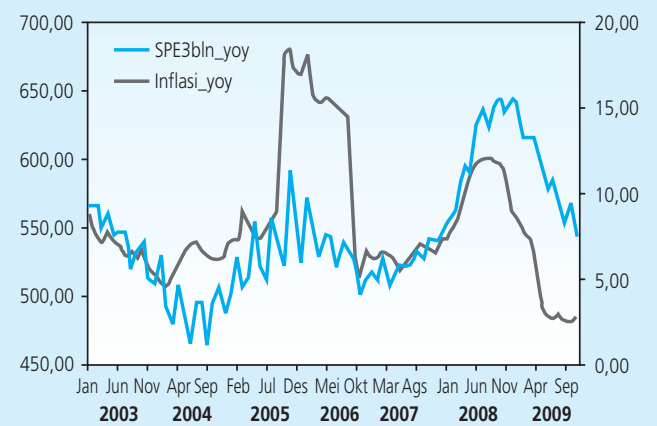

SPE6bln_yoy

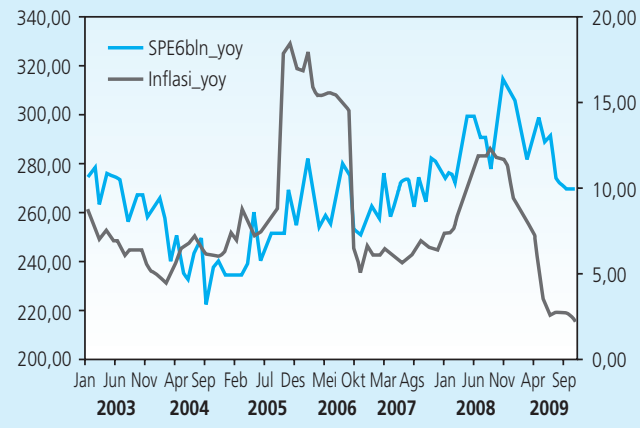

SPE_6bln_yoy

\begin{tabular}{c|c} 
Correlation & SPE_6bln_yoy \\
inflasiyoy+1 & 0.2203 \\
\hline inflasiyoy+2 & $\mathbf{0 . 2 4 7 0}$ \\
\hline inflasiyoy+3 & $\mathbf{0 . 2 4 3 1}$ \\
\hline inflasiyoy+4 & 0.2154 \\
\hline inflasiyoy+5 & 0.2047 \\
\hline inflasiyoy+6 & 0.1549
\end{tabular}

Grafik 8. Korelasi antara Ekspektasi Inflasi dari Suevi Konsumen (Indeks SPE yang Dimodifikasi) dan Inflasi Aktual

Jika kita menggunakan seluruh sampel dari SK dan SPE, keseluruhan tingkat korelasi antara ekspektasi inflasi pengecer terhadap inflasi yang terjadi lebih rendah dari yang kita diperoleh dari konsumen. Hal lebih disebabkan oleh tersedianya data inflasi ekspektasi dari pengecer yang lebih banyak dari data konsumen. Dengan membandingkan kedua survei,

\begin{tabular}{|c|c|c|c|c|c|}
\hline \multicolumn{6}{|c|}{$\begin{array}{l}\text { Tabel 4. Korelasi Ekspektasi Inflasi Konsumen dan } \\
\text { Pedagang Ritel dengan Inflasi Aktual (Periode: Januari 2006-November 2009) }\end{array}$} \\
\hline \multicolumn{3}{|c|}{ Jan06 - Nov09 } & \multicolumn{3}{|c|}{ Jan06 - Nov09 } \\
\hline Correlation & SK3m & SPE3m & Correlation & SK6m & SPE6m \\
\hline inflasi3m-3 & 0.308321 & 0.329546 & inflasi6m-6 & -0.46292 & -0.47199 \\
\hline inflasi3m-2 & 0.533157 & 0.409331 & inflasi6m-5 & -0.28871 & -0.34051 \\
\hline inflasi3m-1 & 0.685564 & 0.51451 & inflasi6m-4 & -0.0963 & -0.07841 \\
\hline inflasi3m & 0.800137 & 0.632471 & inflasi6m-3 & 0.10965 & 0.23695 \\
\hline inflasi3m+1 & 0.795977 & 0.712527 & inflasi6m-2 & 0.324169 & 0.370252 \\
\hline inflasi3m+2 & 0.715949 & 0.66845 & inflasi6m-1 & 0.505773 & 0.504591 \\
\hline inflasi3m+3 & 0.576258 & 0.556668 & inflasi6m-0 & 0.655621 & 0.610855 \\
\hline & & & inflasi6m+1 & 0.741244 & 0.675028 \\
\hline & & & inflasi6m+2 & 0.773329 & 0.681516 \\
\hline & & & inflasi6m+3 & 0.757868 & 0.666486 \\
\hline & & & inflasi6m+4 & 0.72652 & 0.666332 \\
\hline & & & inflasi6m+5 & 0.690567 & 0.614218 \\
\hline & & & inflasi6m+6 & 0.604644 & 0.522138 \\
\hline
\end{tabular}


kita analisis korelasi yang mencakup periode yang sama pada kedua survei ditunjukkan pada Tabel 4. Kita beruntung karena periode saat survei konsumen dan pengecer tersedia bersamaan dengan periode penerapan Inflation Targeting Framework oleh Bank Indonesia.

Seperti yang dapat dilihat di Tabel 4, balance scores SPE 3 bulan menunjukkan korelasi lebih tinggi terhadap tingkat inflasi di masa depan daripada tingkat inflasi yang terjadi saat itu dan sebelumnya. Sejalan dengan apa yang kita di temukan ketika menggunakan seluruh sampel dari kedua survei, dibanding konsumen retailer menunjukkan perilaku yang lebih forward looking dan lebih sedikit memperhatikan tingkat inflasi aktual ketika membentuk ekspektasi inflasi di 3 bulan selanjutnya. Hasil berbeda ditunjukkan pada balance scores 6 bulan dimana balance scores SK dan SPE menunjukkan pola korelasi yang sama dengan tingkat inflasi aktual dan di masa mendatang. Dalam pembentukan ekspektasi inflasi 6 bulan ke depan, baik konsumen maupun pedagang ritel, setelah implementasi ITF, menunjukkan perilaku forward looking dengan lebih sedikit dipengaruhi dari tingkat inflasi saat ini.
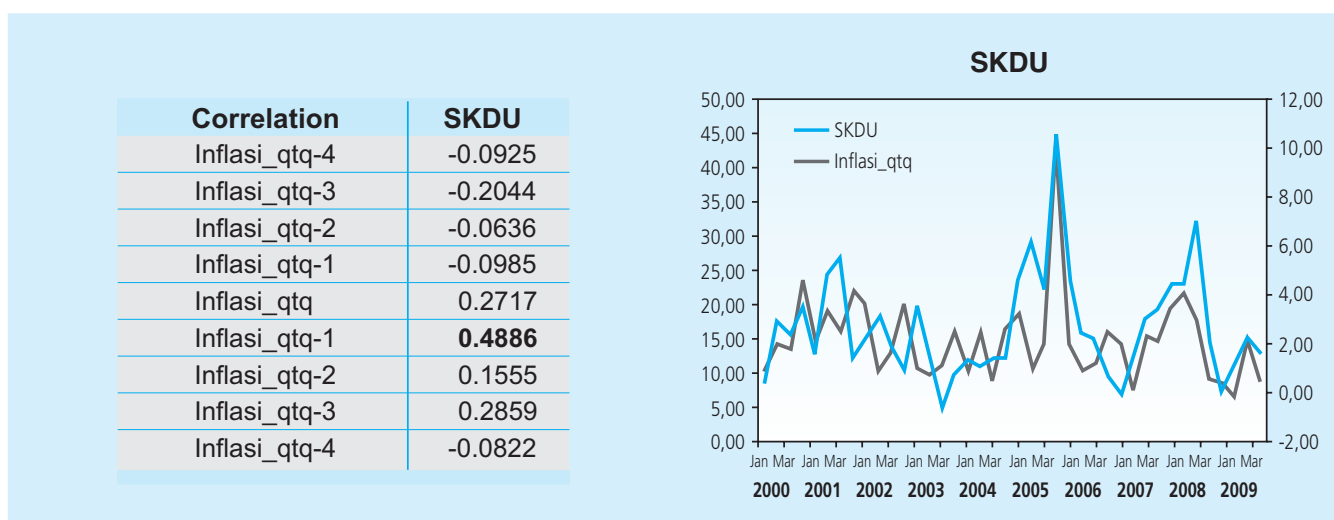

Grafik 9.

Korelasi Ekspektasi Inflasi dari Survei Bisnis (SKDU) dan Inflasi Aktual

Korelasi antara ekspektasi inflasi perusahaan dan inflasi aktual diperlihatkan pada Grafik 9. Korelasi tertinggi terjadi antara ekspektasi inflasi perusahaan dan inflasi actual pada kuartal berikutnya, yang merupakan jangka waktu peramalan yang diinginkan. Dari sini kita dapat menyimpulkan bahwa dibandingkan dengan konsumen dan pedagang ritel, perusahaan menunjukkan ekspektasi inflasi yang lebih "rasional". Ini adalah penemuan awal yang perlu ditelusuri lebih jauh karena hanya berdasarkan analisis korelasi dan menggunakan pengukuran "kualitatif" dalam ekspektasi inflasi. Analisis dalam 2 bagian selanjutnya diharapkan dapat memberikan lebih banyak argumen mengenai temuan ini.

Karena balance scores SKDU seharusnya sesuai dengan pergerakan harga kuartal berikutnya, kita menambah 3 balance scores kuartal sebelumnya dengan balance scores 
saat ini untuk mendapat ukuran ekspektasi inflasi yoy. Hasil yang berbeda ditemukan, di mana korelasi tertinggi adalah dengan tingkat inflasi yoysaat ini. Tetapi korelasi dengan inflasi kuartal berikutnya masih cukup tinggi. Hal ini mungkin karena korelasi antara tingkat inflasi kwartalan kuartal saat ini dan sebelumnya untuk yoy, lebih tinggi dibandingkan dengan korelasi tingkat inflasi kuartal saat ini dan sebelumnya dengan qtq. Dari Grafik 10, terlihat bahwa pergerakan ekspektasi inflasi perusahaan pada kuartal berikutnya meniru pergerakan inflasi aktual dengan relatif baik.

\begin{tabular}{c|c} 
Correlation & SKDU_yoy \\
Inflasi-3 & 0.0122 \\
\hline Inflasi-2 & 0.3476 \\
\hline Inflasi-1 & 0.7021 \\
\hline Inflasi & $\mathbf{0 . 8 8 4}$ \\
\hline Inflasi+1 & 0.7124 \\
\hline Inflasi+2 & 0.4297 \\
\hline Inflasi+3 & 0.0217
\end{tabular}

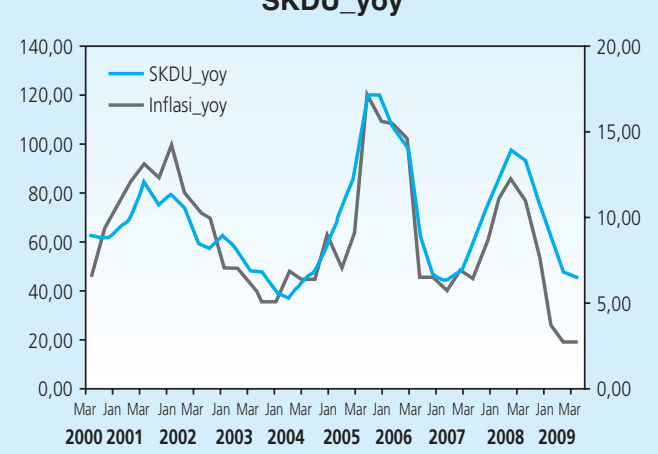

Grafik 10.

Korelasi Ekspektasi Inflasi dari Survei Bisnis (Indeks SKDU ‘Termodifikasi’) dan Inflasi Aktual

Kita menganalisis korelasi data concensus forecast dengan dua pengukuran inflasi, yakni rata-rata inflasi kuartal yoy dan inflasi kuartal yoy akhir periode. Karena variasi yang kecil antara inflasi yoy bulanan dalam satu kuartal (terlihat di Lampiran), maka hasil korelasi juga menunjukkan hasil yang serupa (Grafik 11). Hal ini menegaskan fakta bahwa kita dapat menggunakan data CF sebagai proxy yang sangat baik untuk ekspektasi inflasi kuartalan yoy akhir periode. Dari Grafik 11, kita mengetahui bahwa, seiring meningkatnya jangka waktu peramalan, korelasi antara peramalan dengan inflasi aktual menurun. Semua peramalan (terlepas dari jangka waktu peramalan) menunjukkan korelasi yang signifikan terhadap tingkat inflasi kuartal saat ini dan berikutnya. 
Consensus Forecast $1 \mathrm{Q}$

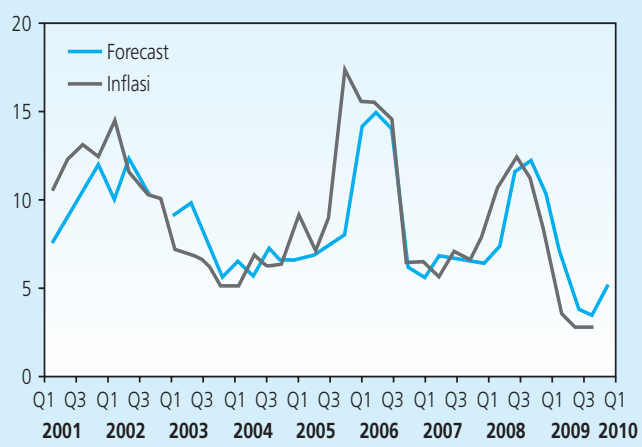

Consensus Forecast $3 Q$

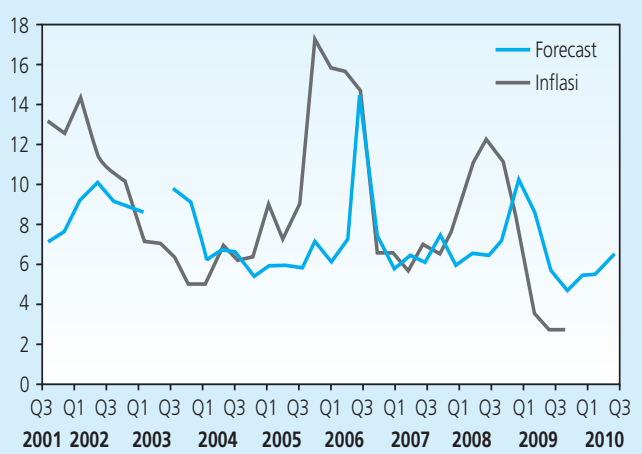

Consensus Forecast $5 \mathrm{Q}$

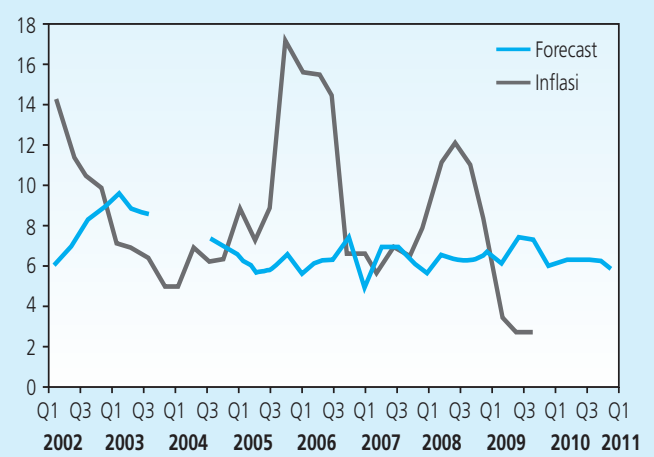

Consensus Forecast 2Q

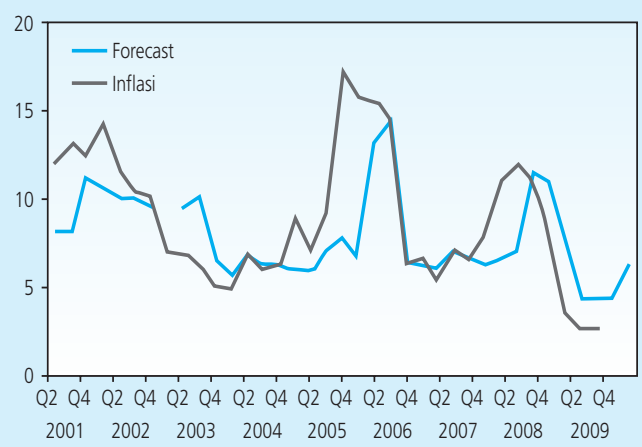

Consensus Forecast $4 \mathrm{Q}$

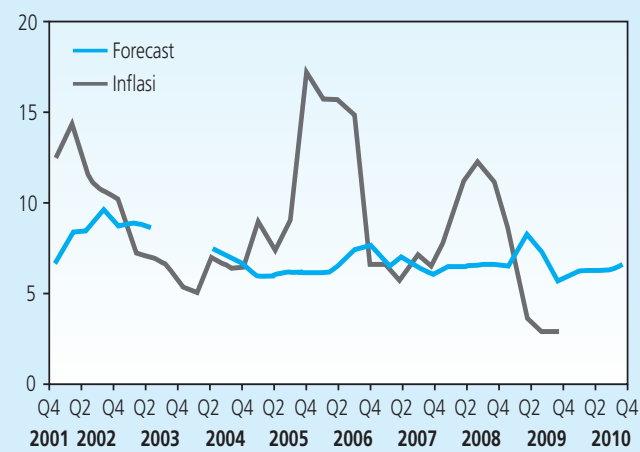

Consensus Forecast $6 \mathrm{Q}$

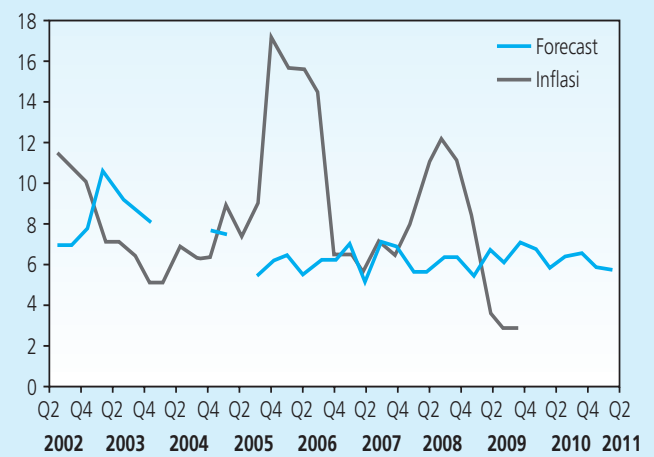

Grafik 11.

Ekspektasi Inflasi dari Concensus forecast dan Inflasi Aktual 
Correlation of CF Measures of Infllation Expectation with Actual Inflation (end of quarter yoy inflation)

\begin{tabular}{c|c|c|c|c|c|c} 
Horizon & CF_1Q & CF_2Q & CF_3Q & CF_4Q & CF_5Q & CF_6Q \\
-4 & -0.2061 & -0.1735 & -0.1048 & -0.1226 & 0.0676 & -0.1212 \\
-3 & -0.0326 & -0.0375 & 0.0982 & 0.1424 & 0.2500 & 0.1455 \\
-2 & 0.2812 & 0.0521 & 0.0986 & 0.2812 & 0.3714 & 0.2834 \\
-1 & 0.6178 & 0.4620 & 0.2438 & 0.3999 & 0.4142 & 0.3993 \\
0 & 0.8567 & 0.7031 & 0.6153 & 0.5445 & 0.3386 & 0.5462 \\
1 & $\mathbf{0 . 7 6 5 8}$ & 0.6477 & 0.5166 & 0.4732 & 0.2754 & 0.4727 \\
2 & 0.4032 & $\mathbf{0 . 5 2 4 7}$ & 0.4407 & 0.3370 & 0.1300 & 0.3413 \\
3 & -0.0260 & 0.0823 & $\mathbf{0 . 2 0 2 5}$ & 0.0846 & -0.0775 & 0.0974 \\
4 & -0.3659 & -0.2925 & -0.2932 & $-\mathbf{0 . 2 0 0 3}$ & -0.1949 & -0.2024 \\
5 & & & -0.3624 & -0.3529 & $\mathbf{- 0 . 3 0 9 7}$ & -0.3617 \\
6 & & & & & -0.3466 & $-\mathbf{0 . 4 3 3 4}$
\end{tabular}

Correlation of CF Measures of Infllation Expectation with Actual Inflation (average monthly yoy inflation in a quarter)

\begin{tabular}{c|c|c|c|c|c|c} 
Horizon & CF_1Q & CF_2Q & CF_3Q & CF_4Q & CF_5Q & CF_6Q \\
-4 & -0.3000 & -0.2506 & -0.1646 & -0.2041 & -0.0359 & -0.0458 \\
-3 & -0.1525 & -0.0949 & 0.0129 & 0.0357 & 0.1481 & 0.1387 \\
-2 & 0.2118 & 0.0006 & 0.0628 & 0.2213 & 0.2999 & 0.2484 \\
-1 & 0.5822 & 0.4019 & 0.1649 & 0.3321 & 0.3650 & 0.3317 \\
0 & 0.8626 & 0.7105 & 0.6092 & 0.5231 & 0.3376 & 0.3241 \\
1 & $\mathbf{0 . 8 0 7 6}$ & 0.6722 & 0.5732 & 0.5080 & 0.3157 & 0.2994 \\
2 & 0.4521 & $\mathbf{0 . 5 6 2 8}$ & 0.4606 & 0.3806 & 0.1884 & 0.1917 \\
3 & 0.0417 & 0.1446 & $\mathbf{0 . 2 7 6 9}$ & 0.1543 & -0.0113 & -0.0257 \\
4 & -0.3185 & -0.2556 & -0.2488 & $-\mathbf{0 . 1 3 0 9}$ & -0.1149 & -0.1445 \\
5 & & & -0.3679 & -0.3323 & $-\mathbf{0 . 2 7 9 3}$ & -0.2669 \\
6 & & & & & -0.3158 & $\mathbf{- 0 . 2 8 8 7}$
\end{tabular}

Tabel 5 menunjukkan beragam pengukuran akurasi dari ekspektasi inflasi pelaku-pelaku yang berbeda. Dalam tabel ini, akurasi data CF didasarkan pada perbandingan dengan inflasi yoy kuartalan akhir periode. Ekspektasi Inflasi dari Concensus forecast menunjukkan hasil yang sebanding dengan seri ekspektasi inflasi yang dihasilkan oleh model SSMX. Pengukuran CF dan SKDU mengenai ekspektasi inflasi juga sebenarnya relatif sama, tetapi pengukuran SKDU hanya tersedia dalam publikasi kuartal ketiga. Dari tabel tersebut, dapat disimpulkan bahwa di antara semua survei yang melaporkan tingkat ekspektasi inflasi (bukan balance scores), Concensus forecast memiliki kinerja yang paling baik dalam hal keakuratan prediksi tingkat inflasi pada jangka waktu peramalan yang dimaksud. Perbandingan kinerja akurasi CF yang beragam pada Tabel 5 dan 5.4, sekali lagi menegaskan bahwa kita dapat menggunakan data CF sebagai proxy yang tepat dari ekspektasi inflasi yoy kuartalan akhir periode. 


\begin{tabular}{|c|c|c|c|c|c|}
\hline \multicolumn{6}{|c|}{$\begin{array}{l}\text { Tabel } 5 . \\
\text { Akurasi Pengukuran Survei Ekspektasi Inflasi }\end{array}$} \\
\hline Tabel Akurasi & ME & MAE & RMSE & TIC & U-Theil \\
\hline CF_1Q(yоу) & 0.62 & 1.59 & 2.29 & 0.94 & 0.12 \\
\hline CF_2Q(yоy) & 1.08 & 2.21 & 3.20 & 0.85 & 0.18 \\
\hline CF_3Q(yoy) & 1.49 & 2.98 & 3.97 & 0.83 & 0.23 \\
\hline CF_4Q(yoy) & 1.86 & 3.34 & 4.44 & 0.78 & 0.26 \\
\hline CF_5Q(yoy) & 1.88 & 3.58 & 4.65 & 0.78 & 0.28 \\
\hline CF_6Q(yoy) & 1.76 & 3.63 & 4.64 & 0.79 & 0.28 \\
\hline SSMX(yoy) & -0.62 & 4.84 & 7.24 & 0.87 & 0.16 \\
\hline $\operatorname{ssMX}(q t q)$ & -0.07 & 2.59 & 4.03 & 1.01 & 0.37 \\
\hline SKDU_4QYOY(Q4) & 0.32 & 4.52 & 5.28 & 0.73 & 0.29 \\
\hline SKDU_3QYOY(Q1) & 0.56 & 3.87 & 4.40 & 0.45 & 0.24 \\
\hline SKDU_2QYOY(Q2) & 0.63 & 3.50 & 4.29 & 0.44 & 0.23 \\
\hline SKDU_1Q(Q3) & 0.49 & 2.85 & 3.46 & 0.35 & 0.19 \\
\hline
\end{tabular}

TIC (Theil Inequality Coefficient) memungkinkan kinerja data survei ekspektasi inflasi dapat dibandingkan dengan prediksi naif (atau random walk) inflasi. TIC kurang dari 1 dikatakan melampaui perkiraan naif; ME = Mean Error; MAE = Mean absolute error. RMSE = Root Mean Square Error. U-Theil mengukur sejauh mana ekspektasi inflasi berbeda dari inflasi aktual. Nilai yang mendekati 0 menunjukkan akurasi perkiraan yang lebih besar

Tabel 6. Akurasi Pengukuran CF dari Ekspektasi Inflasi (Dibandingkan dengan rata-rata inflasi yoy dari setiap kuartal)

Tabel Akuras
CF_1Q(yoy)
CF_2Q(yoy)
CF_3Q(yoy)
CF_4Q(yoy)
CF_5Q(yоy)
CF_6Q(yоy)

ME
0.65
1.14
1.59
1.99
2.00
1.87

MAE
1.34
2.12
2.89
3.30
3.57
3.58

RMSE
2.17
3.19
3.99
4.53
4.80
4.77

TIC
0.84
0.81
0.79
0.76
0.78
0.78

U-Theil
0.12
0.18
0.23
0.27
0.29
0.29

Sama halnya pada bab sebelumnya, kita tidak dapat menggunakan korelasi dan analisa error dengan pengukuran SPP ekspektasi inflasi, jadi kita akan menggunakan analisa grafik. Dari Grafik 12, kita dapat melihat bahwa akurasi ekspektasi inflasi kuartal berikutnya dari SPP relatif baik, karena seluruh poin data inflasi berada di dalam modus range. Sebaliknya, akurasi inflasi akhir tahun dari SPP dan SKDU kurang tepat karena sebagian besar poin data inflasi tidak berada dalam modus range (untuk SPP) atau dekat dengan poin data ekspektasi inflasi (untuk SKDU).

Dari analisa dalam bagian ini, kita dapat menyimpulkan bahwa survei pengukuran ekspektasi inflasi lebih bersifat forward looking, tapi hanya untuk jangka waktu yang cukup singkat (kebanyakan lebih singkat dari jangka waktu yang diinginkan). Balance scores SKDU yang dimodifikasi dan satu kuartal Consensus Forecast menunjukkan korelasi yang sebanding 


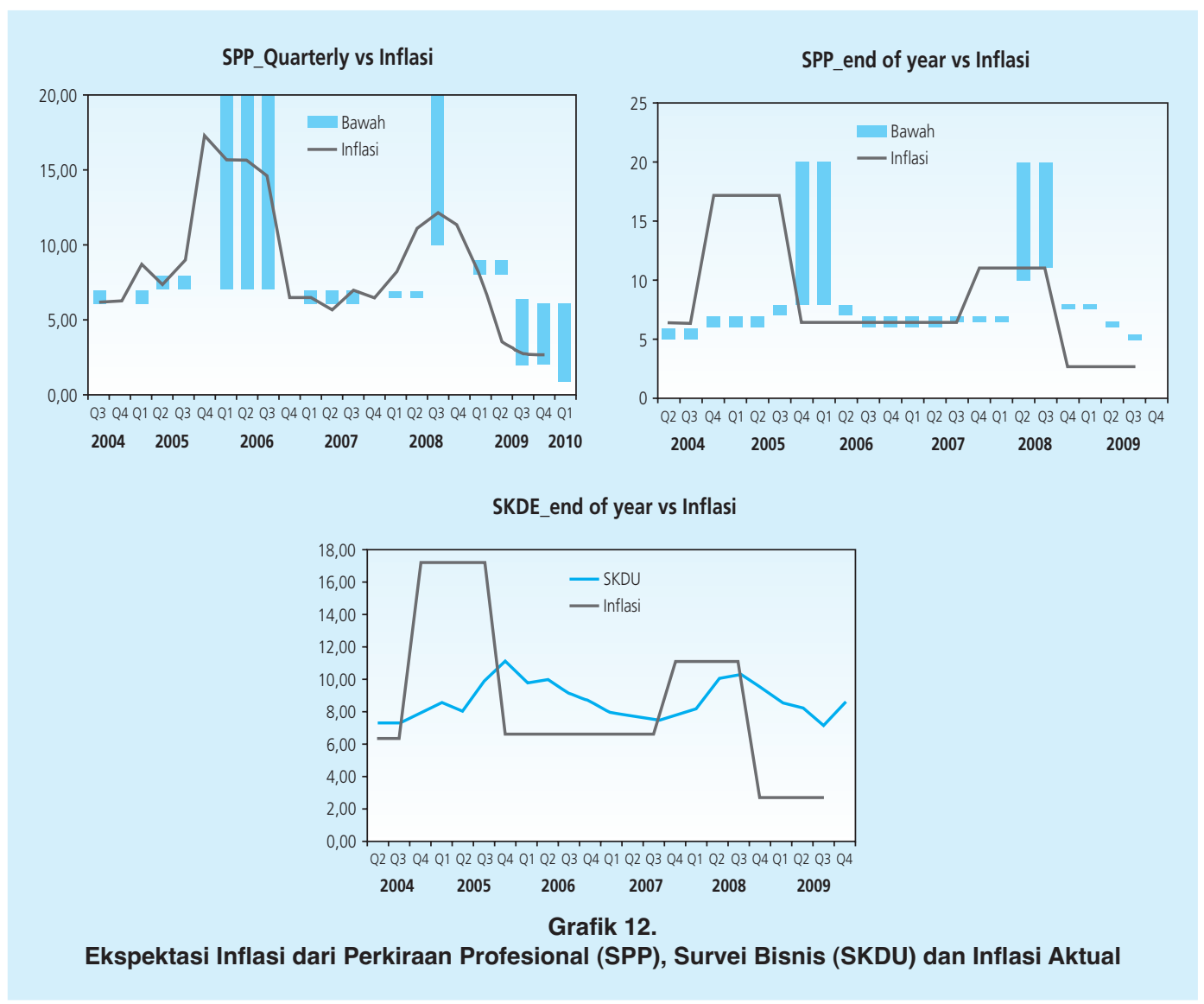

dengan inflasi yoykuartalan berikutnya. Kedua pengukuran tersebut juga menunjukkan perilaku yang sama untuk inflasi yoy saat ini dan inflasi $t-1 t-1$.

Untuk data survei yang mengukur ekspektasi inflasi dua kuartal berikutnya, ekspektasi inflasi dari consensus forecast menunjukkan tingkat korelasi yang lebih tinggi dengan inflasi aktual dibandingkan dengan SK 6 bulan dan SPE 6 bulan yang dimodifikasi. Dari semua survei mengenai tingkat ekspektasi inflasi (bukan balance scores), consensus forecast memiliki tingkat akurasi yang paling baik dalam memprediksi tingkat inflasi pada horison forecast yang diinginkan. Sebagai perbandingan, kita plot balance scores SKDU yang dimodifikasi, ekspektasi inflasi SSMX, satu kuartalan Concensus Forecast, dan data inflasi pada Grafik 13. Dari grafik ini terlihat bahwa SKDU, consensus forecast, dan deretan SSMX yang dimodifikasi dapat mengikuti pergerakan inflasi aktual dengan relatif baik.

Kemiripan gerakan antara consensus forecast satu kuartal dengan balance scores SKDU yang dimodifikasi seperti terlihat dalam Grafik 13, dan kesamaan korelasi kedua indikator dengan inflasi masa lalu, saat ini, dan masa depan, memotivasi kita untuk mengeksplorasi lebih jauh hubungan antara pengukuran-pengukuran tersebut. 


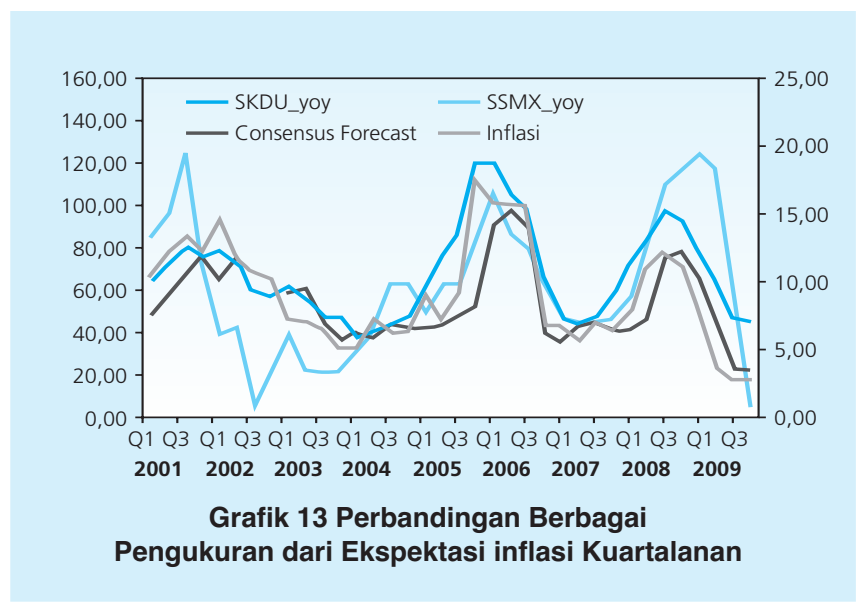

Seperti disebutkan dalam Tabel 1, selain memperlihatkan ekspektasi pergerakan harga dalam bentuk balance scores, SKDU juga memberikan ekspektasi inflasi yoy akhir tahun baik pada publikasi kuartal pertama, kedua, ketiga, dan keempat. Keakuratan perhitungan tersebut dalam memprediksikan inflasi aktual dapat dilihat pada Tabel 5. Karena keterbatasan seri data yang tersedia dari SKDU, kita tidak bisa menerapkan metode yang telah digunakan sebelumnya dalam menganalisis hubungan antara ekspektasi inflasi SKDU dengan consensus forecast.

Tabel 7 menunjukkan tingkat ekspektasi inflasi dari consesnsus forecast dan SKDU yang dipublikasikan. Berbeda dengan hasil yang kita temukan sebelumnya dengan menggunakan balance scores SKDU yang dimodifikasi, tingkat ekspektasi inflasi dalam satu kuartal kedepan antara SKDU dan consensus forecast secara signifikan ternyata berbeda. Perbedaan ini akan muncul dalam horison yang lebih panjang. Meski demikian, perlu mempertimbangkan bahwa poin data dalam perbandingan ini jumlahnya terbatas, sehingga kita tidak dapat mengamati hubungan yang sebenarnya. Tetapi jika kita hanya fokus pada data yang disajikan di Tabel 7 , kita dapat melihat bahwa consensus forecast memiliki tingkat akurasi yang lebih tinggi dalam memprediksi inflasi aktual dibandingkan dengan SKDU.

\begin{tabular}{|c|c|c|c|c|c|c|c|c|c|}
\hline \multicolumn{10}{|c|}{$\begin{array}{l}\text { Tabel } 7 . \\
\text { Consensus forecast vs SKDU ( data tingkat inflasi ) }\end{array}$} \\
\hline \multirow{2}{*}{ Year } & \multirow{2}{*}{ Actual Inflation } & \multicolumn{4}{|c|}{ Consensus Forecast } & \multicolumn{4}{|c|}{ SKDU } \\
\hline & & $4 Q$ & $3 Q$ & $2 Q$ & $1 Q$ & $4 Q$ & $3 Q$ & $2 Q$ & $1 Q$ \\
\hline 2001 & 12.55 & 6.80 & 7.70 & 11.10 & 11.80 & - & - & - & - \\
\hline 2002 & 9.95 & 8.90 & 9.00 & 9.50 & 9.00 & - & - & - & - \\
\hline 2003 & 5.16 & 9.30 & 9.10 & 6.50 & 5.80 & 7.56 & 9.5 & 9 & 8.02 \\
\hline 2004 & 6.40 & 6.50 & 5.50 & 6.20 & 6.50 & 7.89 & 7.37 & 7.3 & 7.37 \\
\hline 2005 & 17.11 & 6.00 & 7.00 & 7.50 & 8.10 & 11.08 & 8.37 & 8.06 & 9.75 \\
\hline 2006 & 6.60 & 7.70 & 7.40 & 6.40 & 6.10 & 8.63 & 9.81 & 9.86 & 9.2 \\
\hline 2007 & 6.59 & 6.10 & 7.40 & 6.60 & 6.50 & 7.75 & 7.89 & 7.6 & 7.47 \\
\hline 2008 & 11.06 & 6.60 & 7.10 & 11.40 & 12.10 & 9.54 & 8.23 & 10.06 & 10.17 \\
\hline 2009 & 2.78 & 5.80 & 4.90 & 4.30 & 3.50 & 8.48 & 8.48 & 8.23 & 7.17 \\
\hline
\end{tabular}


Dalam tabel 7, kita juga dapat mengamati bahwa untuk consensus forecast, terdapat koreksi yang signifikan dari horison forecast panjang ke yang lebih pendek. Sedangkan untuk SKDU, kita tidak meendapatkan perilaku yang sama. Tabel 8 dapat mengungkapkan alasan dari perbedaan tersebut. Kita menerapkan metode yang digunakan oleh Harmanta (2009) untuk menguji apakah ekspektasi inflasi sejalan dengan target yang ditetapkan oleh pemerintah. Kita hanya menggunakan ekspektasi inflasi 4 kuartal kedepan dari kedua survei tersebut karena tidak seperti horison yang lebih pendek, terdapat kemungkinan keduanya dipengaruhi oleh target pemerintah. .

Dari kolom 7a dan 7b, terlihat bahwa consensus forecast 4 kuartal kedepan menjangkar ke target inflasi pemerintah. Sedangkan ekspektasi inflasi SKDU menjangkar untuk periode satu tahun (2006). Dari sini dapat disimpulkan bahwa kredibilitas target inflasi pemerintah lebih tinggi di mata responden consensus forecast dibandingkan dengan responden SKDU. Pertanyaannya, seberapa besar perbedaan ini dapat mempengaruhi dinamika inflasi aktual? Analisa dalam dua bagian berikutnya akan memberikan penjelasan dari pertanyaan ini dengan membandingkan efek guncangan dari perhitungan ekspektasi inflasi yang berbeda, terhadap dinamika inflasi aktual, lalu membandingkannya dengan menguji informasi mengenai hal-hal tersebut dalam memprediksi tingkat inflasi saat ini dan di masa yang akan datang.

\begin{tabular}{|c|c|c|c|c|c|c|c|c|c|}
\hline \multirow{3}{*}{ Year } & \multicolumn{9}{|c|}{$\begin{array}{c}\text { Tabel } 8 . \\
\text { Consensus forecast, SKDU (data tingkat inflasi) dan target inflasi BI. }\end{array}$} \\
\hline & \multirow{2}{*}{ Actual Inflation } & \multicolumn{2}{|c|}{ Inflation Expectation } & \multirow{2}{*}{ Target } & \multirow{2}{*}{ Mistake } & \multicolumn{2}{|c|}{ Surprise } & \multicolumn{2}{|c|}{ Anchoring } \\
\hline & & CF_4Q & SKDU & & & CF_4Q & SKDU & CF_4Q & SKDU \\
\hline 1 & 2 & $3 a$ & $3 b$ & 4 & 5 & $6 a$ & $6 b$ & $7 a$ & $7 c$ \\
\hline 2001 & 12.55 & 6.8 & - & $4-6$ & 6.55 & -5.75 & - & 0.8 & - \\
\hline 2002 & 9.95 & 8.9 & - & $9-10$ & 0 & -1.05 & - & -0.1 & - \\
\hline 2003 & 5.16 & 9.3 & 7.56 & $8-10$ & -2.84 & 4.14 & 2.40 & -2.84 & -0.44 \\
\hline 2004 & 6.40 & 6.5 & 7.89 & $4.5-6.5$ & 0 & 0.10 & 1.49 & 0.00 & 1.39 \\
\hline 2005 & 17.11 & 6 & 11.08 & $5-7$ & 10.11 & -11.11 & -6.03 & 0.00 & 4.08 \\
\hline 2006 & 6.60 & 7.7 & 8.63 & $7-9$ & -0.40 & 1.10 & 2.03 & 0.00 & 0.00 \\
\hline 2007 & 6.59 & 6.1 & 7.75 & $5-7$ & 0 & -0.49 & 1.16 & 0.00 & 0.75 \\
\hline 2008 & 11.06 & 6.6 & 9.54 & $4-6$ & 5.06 & -4.46 & -1.52 & 0.60 & 3.54 \\
\hline 2009 & 2.78 & 5.8 & 8.48 & $3.5-5.5$ & -0.72 & 3.02 & 5.70 & 0.30 & 2.98 \\
\hline
\end{tabular}

Catatan:

Kolom 7 dihitung dari selisih batas atas atau batas bawah dari target (yang paling dekat dengan ukuran ekspektasi inflasi) dengan ukuran ekspektasi inflasi, Kolom $5=2-4$, Kolom $6=3-2$, Kolom $7=3-4$

\subsection{Efek pada Inflasi Aktual}

Untuk menganalisa apakah perhitungan dari setiap survei dari ekspektasi inflasi mempengaruhi dinamika inflasi aktual, kita mengestimasi model VAR bivariat dengan inflasi dan ukuran ekspektasi inflasi sebagai variabel endogen. Untuk mengidentifikasi guncangan terhadap inflasi yang diharapkan, kita mengasumsikan bahwa tingkat inflasi bereaksi seketika terhadap guncangan ekspektasi inflasi . Sedangkan ekspektasi inflasi bereaksi dengan lag satu periode dalam fluktuasi inflasi aktual. Hal ini didasarkan pada dekomposisi Cholesky, di mana 
ekspektasi inflasi diurutkan sebelum inflasi aktual. Pengurutan ini telah menangkap asumsi identifikasi yang kita ambil, yakni bahwa ekspektasi inflasi bersifat contemporenously predetermined.. Untuk mengeksplorasi keterkaitan dinamis antara inflasi actual dan ekspektasi inflasi, kita menggunakan fungsi impuls respon (impulse response function) dan dekomposisi varians (variance decomposition).

Metode dan asumsi yang digunakan di dalam bagian ini mirip dengan yang digunakan oleh Gnaan dkk. (2009) dan Leduc dkk. (2007). Dalam kasus ini kita salah satu variabel dalam model masing-masing memiliki unit root sementara yang lain stasioner (kecuali untuk SK6m dan model SPE6m_yoy, di mana kedua variabel endogen adalah non-stasioner). Karena keterbatasan data, dalam beberapa model, kita tidak dapat menolak bahwa inflasi memiliki satu unit rootkita kita. Secara hati-hati kita mengestimasi semua model VAR menggunakan variabel yang berbeda.

Dalam kasus SK6m dan SPE6m_yoy, tes kointegrasi Johansen menunjukkan bahwa tidak ada kointegrasi antar-variabel endogen yang digunakan dalam model. Kita mengestimasi model VAR bi-variate dengan dua lag variabel endogen. Hasilnya robust sehubungan dengan dimasukkannya lag tambahan ini. Selain itu, karena rentang waktu data yang pendek (terutama untuk data dengan frekuensi kuartalan), kita hanya menyertakan dua lag dalam spesifikasi yang dipilih.

Pada bagian ini, kita mengelompokkan fungsi impuls respon (impulse response function) untuk model yang memiliki frekuensi dan kompatibilitas yang sama dengan ukuran inflasi tertentu ( $q$ tq, 6 bulan atau yoy). Kelompok pertama, kita menguji pergitungan SK dan SPE dari ekspektasi inflasi untuk jangka wkatu peramalan 3 dan 6 bulan (original balance scores). Pada sesi sebelumnya kita telah menemukan bahwa pengukuran-pengukuran ini menunjukkan heterogenitas yang sangat rendah, ekspektasi inflasi retailer mempengaruhi ekspektasi inflasi konsumen 1 bulan dan ekspektasi inflasi konsumen dipengaruhi oleh ekspektasi inflasi retailer. Hasil dari fungsi impuls respon sejalan dengan temuan ini.

Seperti yang dapat kita lihat di Grafik 14, guncangan terhadap perubahan ekspektasi konsumen memiliki efek langsung terhadap perubahan inflasi dari periode 1 hingga 2, sedangkan guncangan terhadap perubahan ekspektasi retailer memiliki dampak pada perubahan pada tingkat inflasi pada periode 3. Sayangnya untuk pengukuran 6 bulan kita tidak menemukan fenomena yang sama. Guncangan terhadap pergerakan harga konsumen 6 bulan berikutnya memiliki dampak yang sangat kecil terhadap perubahan tingkat inflasi. Sedangkan guncangan pada perubahan ekspektasi retailer tidak memiliki dampak terhadap inflasi. 
Response of D(INFLASI3M) to D(SK3m)

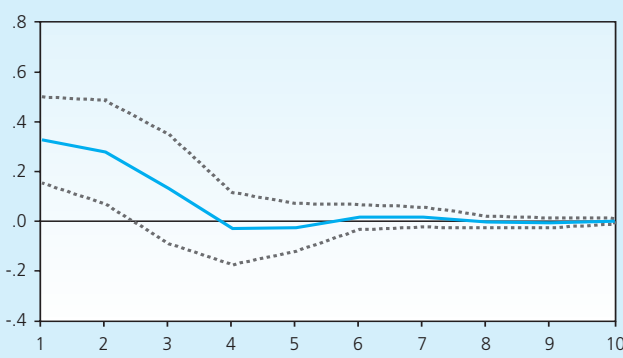

Response of D(INFLASI3M) to D(SPE3m)

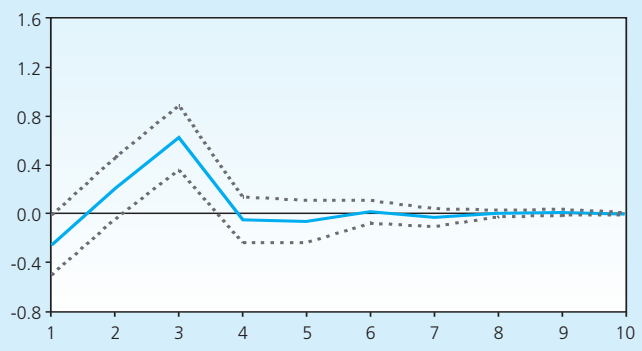

Response of $D(S K 3 m)$ to $D$ (INFLASI3M)

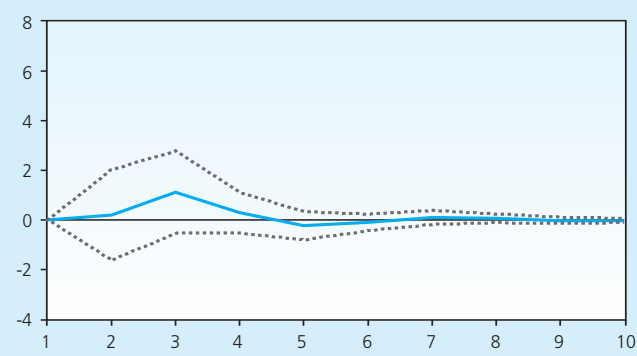

Response of D(SPE3m) to D(INFLASI3M)

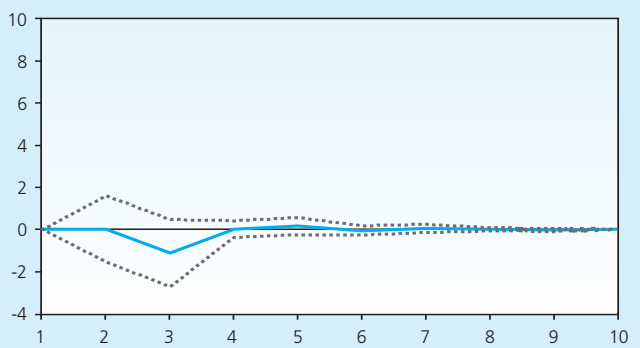

Response of D(INFLASI6M) to D(SK6m)

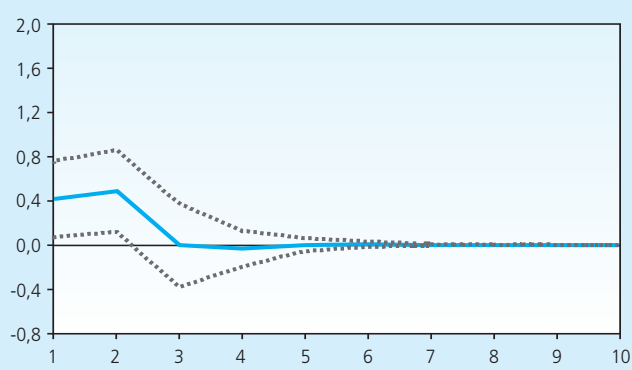

Response of D(INFLASI6M) to D(SPE6m)

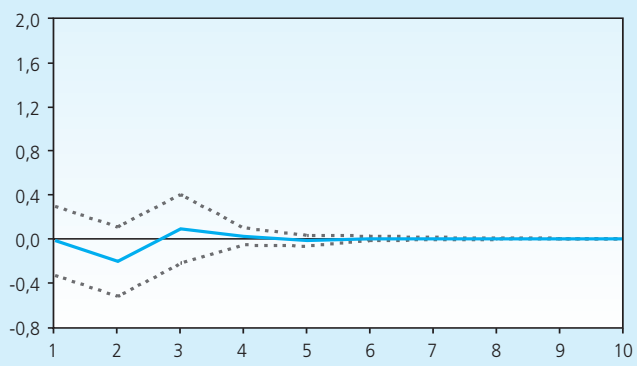

Response of $D(S B T)$ to $D$ (INFLASI6M)

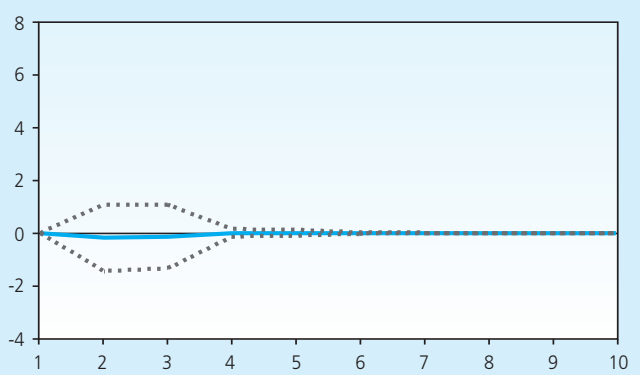

Response of D(SPE6m) to D(INFLASI6M)

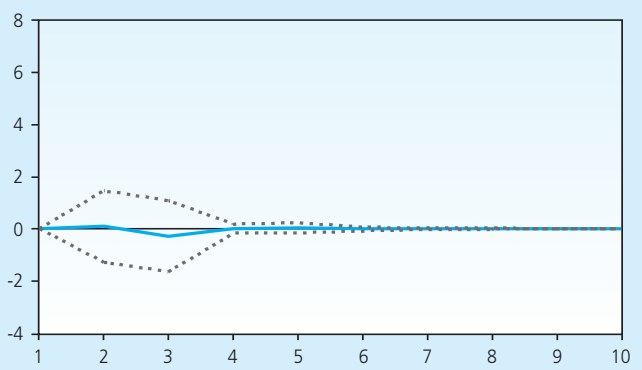

Frequency: Monthly

Grafik 14.

Fungsi impuls respon Pengukuran Survei Konsumen dan Retailer dari Ekspektasi Inflasi 
Response of D(INFLASI QTQ) to D(SKDU)

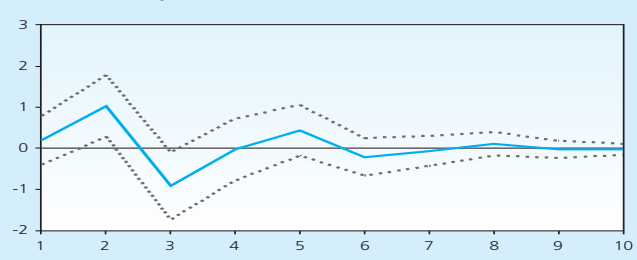

Response of D(INFLASI_YOY) to D(SKDU_YOY)

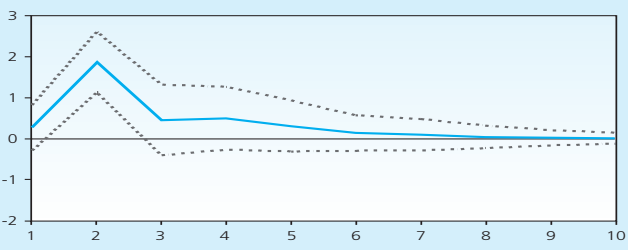

Response of D(INFLASI) to D(CF_1Q)

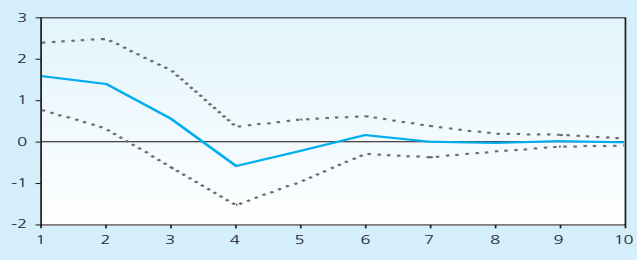

Response of D(INFLASI) to D(CF_2Q)

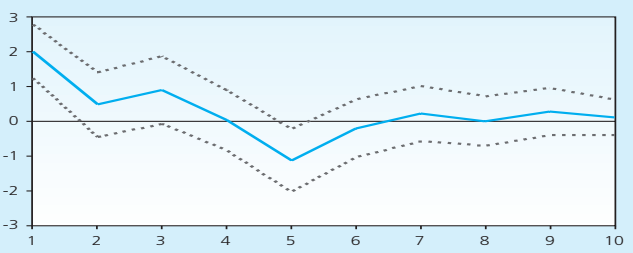

Response of D(INFLASI) to $\mathrm{D}\left(\mathrm{CF} \_3 Q\right)$

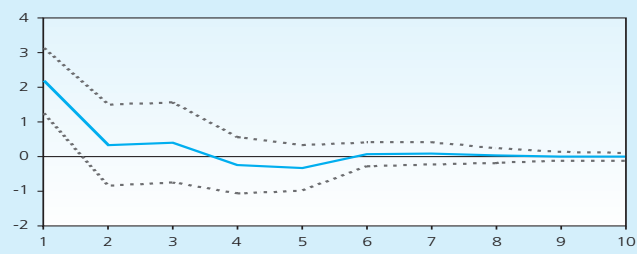

Response of D(INFLASI) to D(CF_4Q)

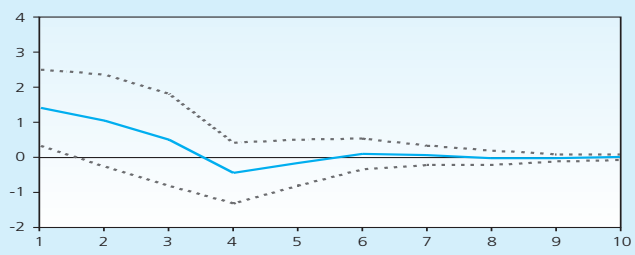

Response of D(SKDU) to D(INFLASI_QTQ)

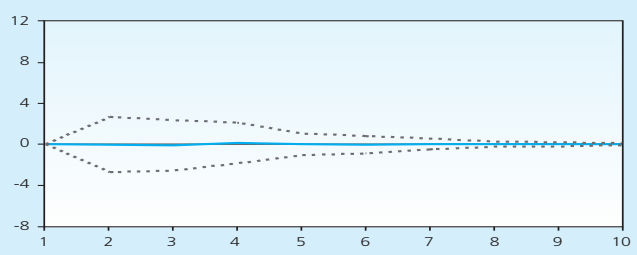

Response of D(SKDU_YOY) to D(INFLASI_YOY)

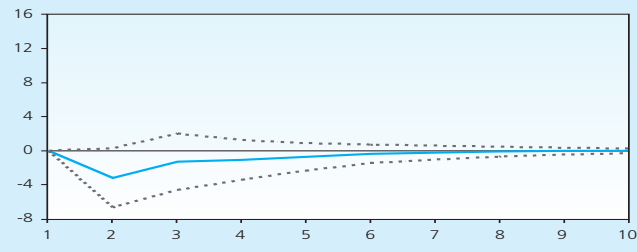

Response of $D\left(C F_{-} 1 Q\right)$ to $D(I N F L A S I)$

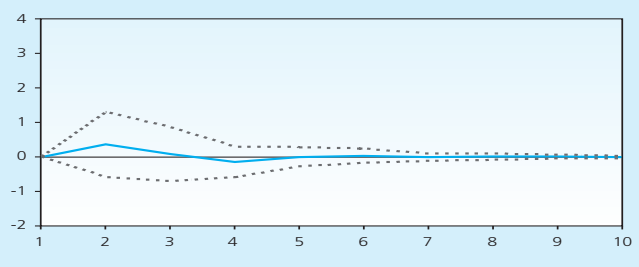

Response of $\mathrm{D}\left(\mathrm{CF} \_2 \mathrm{Q}\right)$ to $\mathrm{D}(\mathrm{INFLASI})$

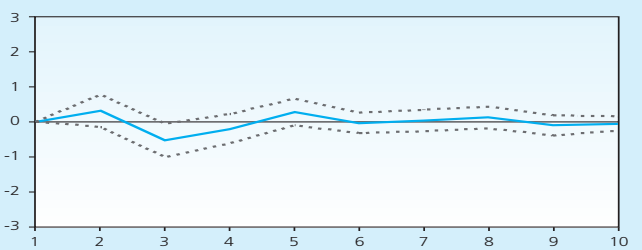

Response of D(CF_3Q) to D(INFLASI)

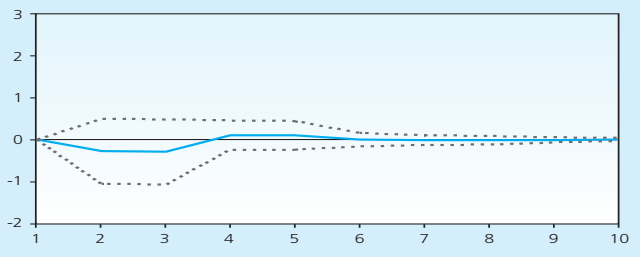

Response of D(CF_4Q) to D(INFLASI)

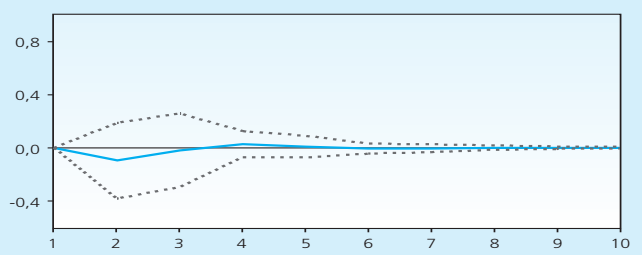

Frequency: Quarterly

Grafik 15. Fungsi impuls respon Pengukuran yang Bervariasi Ekspektasi Inflasi Kuartalan 
Grafik 15 menunjukkan fungsi impuls respon untuk berbagai ukuran ekspektasi inflasi dengan frekuensi kuartalan. Penting untuk dicatat bahwa kita menemukan respon yang berbeda antara guncangan Consensus Forecast 1 kuartal dan balance scores SKDU yang dimodifikasi terhadap dinamika inflasi aktual. Dari sesi sebelumnya, kita menemukan bahwa kedua ukuran tersebut memiliki korelasi yang sama dengan tingkat inflasi yang terjadi di masa lalu, saat ini, dan masa depan. Kita dapat melihat pada Gambar 15 bahwa guncangan pada perubahan ekspektasi inflasi Consensus Forecast memiliki dampak pada perubahan tingkat inflasi pada horison 1 dan 2. Sedangkan guncangan pada perubahan ekspektasi perusahaan berpengaruh pada perubahan inflasi hanya terjadi pada horison 2. Grafik tersebut juga menunjukkan bahwa guncangan terhadap perubahan Ekspektasi Inflasi Consensus Forecast (dari horison forecast yang bervariasi) mempengaruhi perubahan tingkat inflasi dimulai dari horison 1. Besar dan lamanya dampak, menurun seiring peningkatan jangka waktu peramalan.

Pada Grafik 16, dibandingkan dengan ukuran survei ekspektasi inflasi yang lain, guncangan terhadap ekspektasi inflasi SK dan SPE yang dimodifikasi, relatif memiliki dampak lebih kecil terhadap dinamika inflasi aktual.
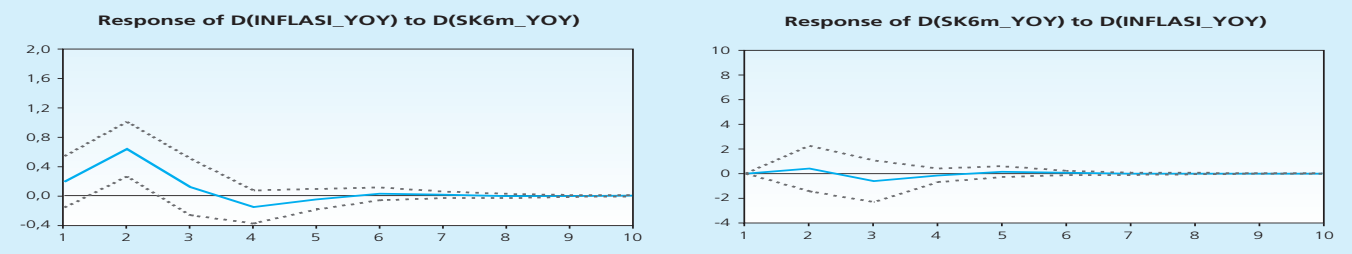

Response of D(INFLASI_YOY) to D(SK3m_YOY)

Response of D(SK3m_YOY) to D(INFLASI_YOY $)$
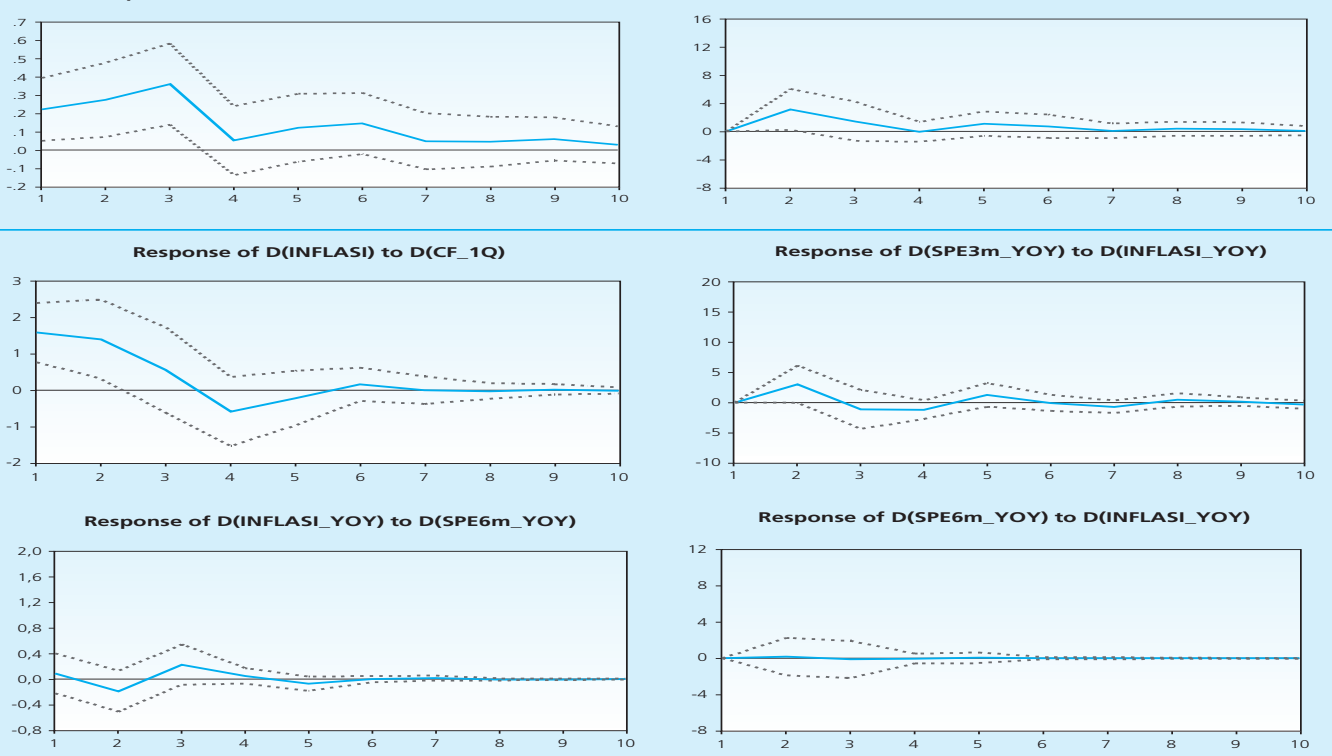

Frequency: Monthly

Grafik 16. Fungsi impuls respon Pengukuran yang Inflasi Ekspektasi Dimodifikasi (SK dan SPE) 
Uji Kusalitas Granger pada Tabel 9 menunjukkan bahwa hampir semua indikator ekspektasi inflasi berpengaruh (granger cause) kepada inflasi, kecuali untuk SPE6m (Survei Penjualan Eceran - 6 bulan). Di sisi lain, inflasi tidak mempengaruhi semua indikator, kecuali untuk SPE3m (Survei Penjualan Eceran-3 bulan) dan CF_2Q (Consensus Forecas $t$-2 kuartal). Berdasarkan Fungsi impuls respon dan hasil uji kausalitas Granger, kita dapat menyimpulkan bahwa hampir seluruh indikator ekspektasi inflasi memiliki dampak terhadap dinamika inflasi aktual. Hasil dari dekomposisi varians inflasi untuk setiap model VAR ditunjukkan pada Table 10. Tergantung pada indikator yang digunakan, kontribusi guncangan ekspektasi inflasi dapat mencapai 75.76\% terhadap variabilitas perubahan inflasi.

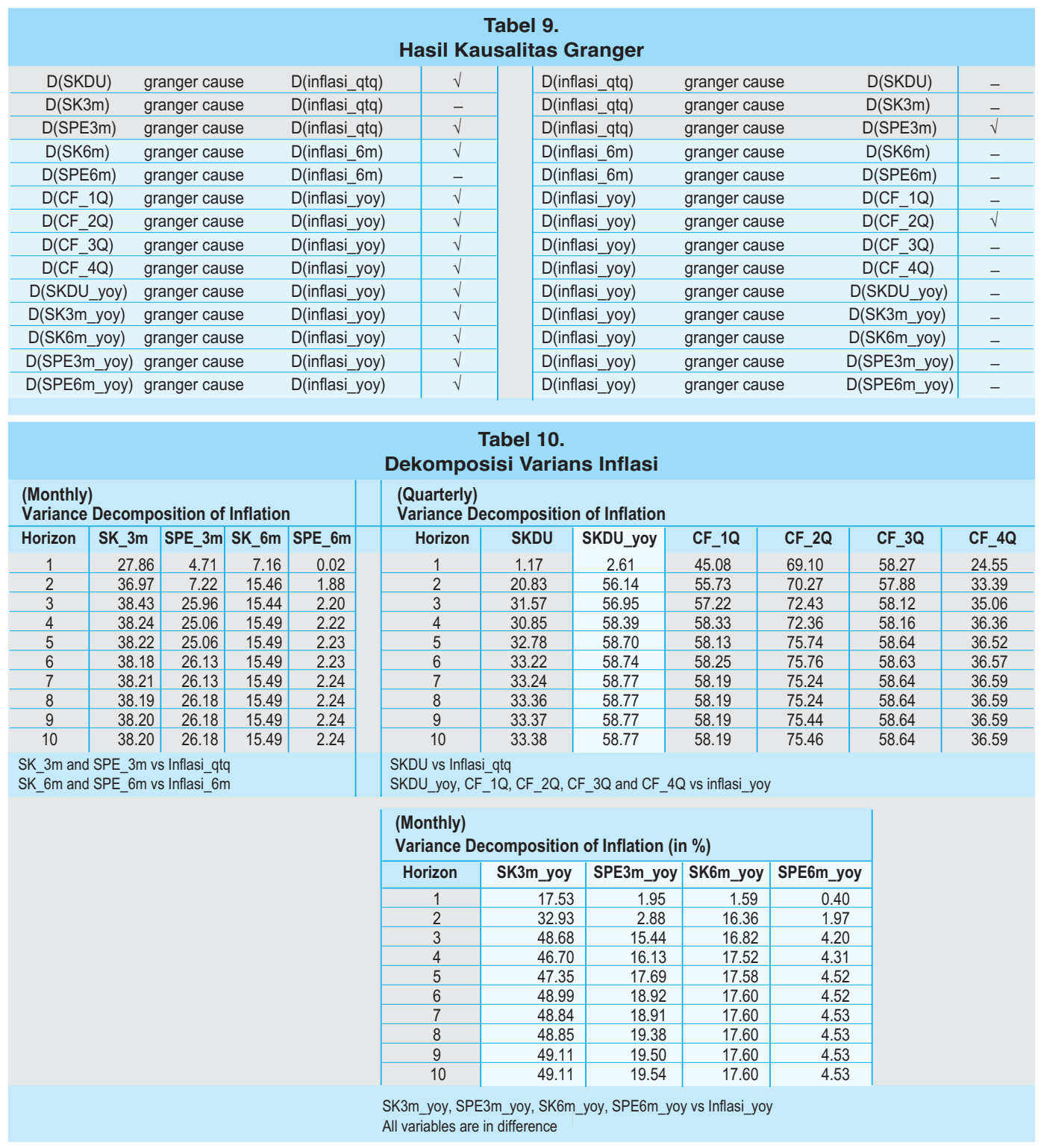




\subsection{Informasi Direksional Dalam Memprediksi Inflasi Saat Ini dan Masa Depan}

Pada sesi ini, kita membahas informasi arah yang dimiliki oleh setiap ukuran ekspektasi inflasi dalam memprediksi tingkat inflasi saat ini dan masa depan. Walaupun ukuran survei ekspektasi inflasi tidak akurat, mereka masih tetap berguna untuk melengkapi indikator ekonomi.

Kita mengikuti metode Ranchold (2003) yang menggunakan model inflasi sederhana dengan regressor inflasi masa lalu, output gap dan indeks bobot perdagangan. Model ini merupakan versi perekonomian terbuka dari hybrid New Keynesian Phillips Curve. Untuk tujuan ini, kita menggunakan versi NKPC yang juga digunakan oleh Alamsyah (2008). Kita mengukur kontribusi tambahan data ekspektasi inflasi terhadap daya jelas model (yakni peningkatan $\mathrm{R}^{2}$ ketika data survei dimasukkan ke dalam model). Seperti halnya pada analisis korelasi, kita tidak hanya tertarik pada daya prediktif tambahan data survei terhadap model inflasi pada jangka waktu peramalan yang diinginkan, tapi juga pada saat survei dan setelah survei hingga akhir waktu peramalan.

Regresi Pertama

Regresi Kedua

$$
\begin{aligned}
& : \pi_{t}=\pi_{t-1}+\operatorname{Ogap}_{t}+\text { TOT }_{t} \\
& : \pi_{t}=\pi_{t-1}+\operatorname{Ogap}_{t}+\text { TOT }_{t}+\pi^{e}
\end{aligned}
$$

Dimana $\pi_{t}$ adalah inflasi pada periode $t ; \pi_{t-1}$ adalah inflasi di masa lalu $t$ - 1 ; Ogap adalah output gap pada periode $t$; TOT adalah nilia tukar perdagangan (term of trade), dan $\pi^{e}$ adalah ekspektasi inflasi. Daya prediktif tambahan dihitung sebagai selisih R-square dari kedua regresi.

Idealnya kita melakukan regresi pada data level, namun berdasarkan uji root unit, beberapa variabel adalah I(1), sehingga kita harus melakukan regresi pada first difference. Pada setiap kasus, uji kointegrasi Johansen menunjukkan semua variabel I(1) tidak terintegrasi (hasil uji kointegrasi unit root ada pada Appendix). Pada setiap regresi yang menggunakan data first difference, interpretasi akan menjadi lebih sulit. Namun karena kita hanya tertarik pada peningkatan (atau penurunan) adjusted- $R^{2}$ model, maka interpretasi ini tidak mejadi persoalan.

Untuk analisis pada sesi ini, kita hanya menggunakan data survei yang sesuai dengan pengukuran inflasi yoy. Dikarenakan hal ini, kita hanya menggunakan versi data SK, SPE, dan SKDU yang dimodifikasi, untuk tambahan data CF. Untuk membandingkannya, kita juga menggunakan seri ekspektasi inflasi yang kita dapatkan dari model SSMX. Data yang tersedia untuk output gap dan TOT hanya dalam frekuansi kuartalan, jadi kita hanya menggunakan data bulan Maret, Juni, September, dan Desember untuk SK dan SPE. Kita tidak dapat menganalisa data SK yang dimodifikasi yang berdasarkan ekspektasi pergerakan harga 3 bulan berikutnya dikarenakan terbatasnya inti data yang tersedia untuk seri ini. 


\begin{tabular}{|c|c|c|c|c|c|c|c|c|c|c|c|}
\hline \multicolumn{12}{|c|}{$\begin{array}{l}\text { Tabel 11. Kontribusi Untuk R2 yang Disesuaikan } \\
\text { Ketika Ukuran Ekspektasi Inflasi ditambahkan dalam Model sederhana Inflasi }\end{array}$} \\
\hline Horizon & CF_1Q & CF_2Q & CF_3Q & $C F \_4 Q$ & CF_5Q & CF_6Q & SPE3bln_yoy & SK6bln_yoy & SPE6bln_yoy & SSMX_yoy & SKDU_yoy \\
\hline 0 & $15 \%$ & $5 \%$ & $28 \%$ & $3 \%$ & $3 \%$ & $5 \%$ & $-4 \%$ & $-6 \%$ & $-1 \%$ & $26 \%$ & $13 \%$ \\
\hline 1 & $21 \%$ & $-4 \%$ & $-1 \%$ & $-2 \%$ & $2 \%$ & $8 \%$ & $17 \%$ & $44 \%$ & $1 \%$ & $5 \%$ & $43 \%$ \\
\hline 2 & $-3 \%$ & $24 \%$ & $3 \%$ & $-7 \%$ & $-7 \%$ & $-6 \%$ & $-3 \%$ & $-8 \%$ & $-3 \%$ & $0.2 \%$ & $3 \%$ \\
\hline 3 & $-6 \%$ & $-5 \%$ & $23 \%$ & $5 \%$ & $-3 \%$ & $-4 \%$ & $-6 \%$ & $-5 \%$ & $-5 \%$ & $5 \%$ & $10 \%$ \\
\hline 4 & & & $28 \%$ & $7 \%$ & $-4 \%$ & $-8 \%$ & & & & & \\
\hline 5 & & & $-7 \%$ & $1 \%$ & $-4 \%$ & $-9 \%$ & & & & & \\
\hline 6 & & & & & $-5 \%$ & $-13 \%$ & & & & & \\
\hline 7 & & & & & & $-11 \%$ & & & & & \\
\hline
\end{tabular}

Dari Tabel 11, kita dapat melihat bahwa penambahan ukuran ekspektasi inflasi CF, SKDU_yoy dan SPE3bln_yoy menambah daya prediksi yang substansial terhadap model sederhana inflasi kuartalan berikutnya. daya prediktif tambahan tertinggi diberikan oleh penambahan SKDU_yoy. SK6bln_yoy menghasilkan tambahan daya prediksi yang sama seperti SKDU_yoy, tapi seri ini sebenarnya dimaksudkan untuk mengukur ekspektasi inflasi 2 kuartal berikutnya. Untuk model inflasi 2 kuartal kedepan, daya prediktif tambahan tertinggi dihasilkan dari penambahan CF_2Q.

Daya prediksi yang signifikan diperoleh ketika eksprektasi inflasi yang diperoleh dari model SSMXditambahkan ke model inflasi periode $t$. Hal ini menunjukkan bahwa tidak seperti indkator survei, seri ini sebenarnya dirancang untuk memprediksi inflasi pada waktu $t$, bukan waktu t+1. Model SSMX tidak sepenuhnya dianggap sebagai model ekspektasi rasional yang konsisten, karena perkiraan model ini berbeda dengan ekspektasi. Hal ini sejalan dengan bukti empiris di Indonesia yang menunjukkan bahwa meski pembentukan inflasi di Indonesia cenderung bersifat forward looking, tapi inflasi masa lalu masih memiliki pengaruh yang signifikan.

Seri CF_1Q dapat digunakan sebagai alternatif untuk ekspektasi inflasi pada model ekonometri makro. Seri ini memberikan informasi tentang arah inflasi kuartal saat ini dan berikutnya. Dibandingkan dengan yang digunakan oleh SSMX, seri ini masih dianggap lebih "rasional" (karena lebih akurat dalam memprediksi tingkat inflasi masa depan), tetapi didasarkan pada proses imperfect foresight (bertentangan dengan SSMX yang menggunakan inflasi aktual dalam mengestimasi ekspektasi inflasi). Perbedaan antara seri CF dan SSMX berkaitan dengan daya prediksi mereka dalam menentukan tingkat inflasi saat ini dan masa depan, disebabkan oleh perbedaan asumsi yang diterapkan dalam proses pembentukan data mereka. Kedua seri ini mewakili ekspektasi yang "tidak sepenuhnya rasional" namun dengan perilaku forward looking yang berbeda. Keuntungan menggunakan seri CF dibandingkan dengan SSMX adalah tingkat perilaku forward looking dalam pembentukan inflasi tidak harus tetap melainkan dapat berubah dari waktu ke waktu. Pilihan menerapkan seri ini pada model makro-ekonometrik harus didasarkan tingkat akurasinya dalam memprediksi inflasi dan variabel makroekonomi lainnya. 
Karena adanya lag pada publikasi data survei, maka untuk tujuan forecasting, Bank Sentral akan tertarik dengan kemampuan model yang dapat memprediksi lebih dari 2 kuartal. Satusatunya data yang tersedia dengan kinerja yang cukup berasal dari Consensus Forecast, namun kinerjanya untuk memprediksi ekspektasi inflasi kuartal 4-6 tidak baik.

Seperti terlihat dari analisis yang telah kita lakukan sepanjang Bab 5, terdapat banyak keterbatasan akibat informasi yang tidak lengkap dan ketidaksesuaian data. Beberapa kriteria informasi ekspektasi inflasi yang "ideal", yang diperlukan untuk analisis kebijakan dan pemodelan adalah:

1. Setiap survei harus memiliki struktur waktu untuk dinamika ekspektasi inflasi dari 1 sampai 4 kuartal ke depan.

2. Ekspektasi inflasi diukur dengan ekspektasi inflasi yoy kwartalan akhir periode

3. Jika tidak memungkinkan untuk memperoleh informasi yang dapat dipercaya dari responden mengenai tingkat ekpektasi inflasi yoy kuartalan akhir periode, maka survei harus memiliki informasi mengenai ekspektasi pergerakan harga yang mencakup 1 hingga 4 kuartal berikutnya (diukur dengan menggunakan metode balance scores). Ekspektasi pergerakan harga harus disertai dengan data persepsi pergarakan harga 1 sampai 4 kwartal kedepan (juga menggunakan metode balance scores). Dengan memiliki kedua ekspektasi dan persepsi balance scores, kita akan memiliki informasi yang cukup untuk mengubah data balance scores menjadi data tingkat ekspektasi inflasi, dengan menggunakan pendekatan CarlsonParkin (seperti dibahas dalam Millet, 2006).

\section{KESIMPULAN}

Penelitian ini menganalisa secara empiris survei inflasi dan memberikan beberapa temuan, pertama, di antara berbagai langkah ekspektasi inflasi di Indonesia, Concensus Forecast (CF) adalah satu-satunya indikator yang memberikan struktur ekspektasi inflasi yang lengkap dari 1 sampai 4 kuartal berikutnya. selain itu CF juga memiliki data bulanan untuk ekspektasi inflasi tahun sekarang dan ekpektasi inflasi tahun berikutnya (rata-rata inflasi bulanan yoy). Kedua, heterogenitas ekspektasi inflasi di antara pelaku ekonomi dan forecaster profesional untuk horison yang singkat (1 kuartal ke depan) sangat rendah. Untuk tujuan pemodelan, hal ini dapat digunakan sebagai dasar asumsi homogennyaekspektasi inflasi diantara para pelaku ekonomi. Ketiga, analisis korelasi dan uji kausalitas granger menunjukkan bahwa ekspektasi inflasi konsumen dipengaruhi oleh ekspektasi inflasi pengecer, dan ekspektasi Inflasi forecaster profesional dipengaruhi oleh ekspektasi inflasi perusahaan.

Ketiga temuan ini mengarahkan pada kesimpulan pertama, ekspektasi inflasi dari berbagai pelaku ekonomi bervariasi satu sama lain dan terdapat spillovers ekspektasi inflasi lintas pelaku ekonomi yang berbeda. Mekanisme bagaimana spillovers ini terjadi merupakan isu yang menarik untuk penelitian lebih lanjut. Diantara survei ekspektasi inflasi yang ada, Concensus Forecast (CF) dapat digunakan sebagai sumber informasi utama dalam menentukan tingkat ekspektasi 
inflasi masyarakat. Kesimpulan kedua, seluruh survei ekspektasi inflasi kuartalan, memnberikan informasi berguna tentang tentang arah inflasi kuartalan berikutnya. Di antara mereka, hanya pengukuran CF yang memberikan informasi berguna tentang inflasi 2 kuartal kedepan, sehingga menjadi informasi paling memadai bagi kebijakan moneter. Untuk memprediksi pergerakan tingkat inflasi di masa depan, data ini dapat didukung dengan survei ekspektasi inflasi lainnya, terutama dari Survei kegiatan Dunia Usaha. Untuk tujuan pemodelan, seri concensus forecast (CF) 1 kuartal ke depan dapat digunakan sebagai alternatif untuk mewakili ekspektasi inflasi dalam model makro-ekonometrik karena seri ini dapat memberikan informasi tentang inflasi kuartal saat ini dan kuartal berikutnya.

Paper ini juga menemukan bahwa ekspektasi inflasi dari survei yang diamati lebih bersifat forward looking, tapi hanya untuk horison yang relatif singkat (kebanyakan kurang dari ekspektasi horison yang dituju). Meskipun besar dan panjang ekspektasi inflasi berbeda-beda, guncangan ekspektasi inflasi secara signifikan mempengaruhi dinamika tingkat inflasi aktual. Di antara semua survei yang menyajikan tingkat ekpektasi inflasi (bukan balance scores), Consensus Forecast memiliki kinerja terbaik dalam hal akurasi dalam memprediksi tingkat inflasi untuk jangka peramalan yang diinginkan. Ini adalah kesimpulan ketiga dari paper ini.

Implikasi kebijakan untuk ketiga kesimpulan di atas sangat jelas. Untuk meningkatkan perannya dalam analisis kebijakan moneter, informasi ekpektasi inflasi dari berbagai survei yang dilakukan saat ini perlu diperbaiki dengan meningkatkan kompatibilitas ekpektasi pengukuran survei yang berbeda dan memperpanjang ketersediaan horison waktu peramalan. 


\section{DAFTAR PUSTAKA}

Alamsyah, Halim, 2008, "Persistensi Inflasi dan Dampaknya terhadap Pilihan dan Respons Kebijakan Moneter di Indonesia", Universitas Indonesia, September 2008.

Anwar, Muslimin and TevyChawwa, 2009 , "Analisis Ekspektasi Inflasi Indonesia Pasca ITF", WP No.9, Bank Indonesia, May 2009.

Curtin, R., 2006 , "Inflation Expectations: Theoretical Models and Empirical Tests", Paper presented at the Narodowy Bank Polski's workshop on "The Role of Inflation Expectations in Modeling and Monetary Policy Making" on February 9 and 10, 2006.

Dewati, Wahyu, Ndari Suryaningsih danTevy Chawwa, 2009, "Revisiting Transmisi Kebijakan Moneter: Pendekatan VAR dan Panel Data", Bank Indonesia, LHP No. 19, December 2009.

Forsells, M. danG. Kenny, 2004, "Survey Expectations, Rationality and the Dynamics of Euro Area Inflation", Journal of Business Cycle Measurement and Analysis.

Gnan, Ernest, Johann ScharlerdanMaria Antoinette Silgoner, 2009, "Inflation ExpectationsRole and Measurement for Monetary Policy," Monetary Policy \& the Economy, Oesterreichische National bank (Austrian Central Bank), issue 2, pages 41-67, August 2009. Harmanta, 2009, "Kredibilitas Kebijakan Moneter dan Dampaknya terhadap Persistensi Inflasi dan Strategi Disinflasi di Indonesia: Dengan Model DSGE", Universitas Indonesia, October 2009.

Kurniati, Yati dan Sahminan, 2008, "Ekstraksi Ekspektasi Inflasi dari Yields Surat Utang Negara", Research Note No. 23, Bank Indonesia, 2008.

Laksmono R, Didi et al., 2000, "Suku Bunga sebagai salah satu indikator ekspektasi inflasi", Buletin Ekonomi Moneter dan Perbankan, Bank Indonesia, Maret 2000.

Leduc, S., K. Sill danT. Stark, 2007, Self-Fulfilling Expectations and the Inflation of the 1970s: Evidence from the Livingston Survey, Journal of Monetary Economics 54(2), 433-459,2007.

Mankiw, N. G., R. Reis danJ. Wolfers, 2003, "Disagreement about Inflation Expectations", NBER Working Paper 9796, 2003.

Millet, F.C., 2006, "Finding the Optimal Method of Quantifying Inflation Expectations On The Basis of Qualitative Survey Data", manuscript, Balliol College, University of Oxford.

SatishRanchhod, 2003, "The Relationship between Inflation Expectations Survey Data and Inflation," Reserve Bank of New Zealand Bulletin, Reserve Bank of New Zealand, vol. 66, December 2003. 
Tjahjono Endi, Haris Munandar danJati Waluyo, 2010, "Revisiting Estimasi Potential Output dan Output Gap Indonesia: Pendekatan Fungsi Produksi berbasis Model", WP No. 02, Bank Indonesia, April 2010.

Whelan, Karl, 2005, "The New-Keynesian Phillips Curve", Lecture Notes EC4010, Trinity College Dublin.

Wuryandani, Gantiah, 2001, "Suku Bunga Riil Ex-Ante sebagai Indikator Arah Kebijakan Moneter", Bank Indonesia, December 2001.

Wuryandani, GantiahdanAbdul M. Ikram and Diah E. Handayani, 2003, "Monetary Policy Transmission Through Inflation Expectation Channel", Transmission Mechanism of Monetary Policy in Indonesia, Bank Indonesia, 2003. 